\title{
XIX. Yüzyılda İngiliz Gezginlerin Kaleminden Osmanlı Yöneticileri ve Yönetim Sistemi
}

\section{The Ottoman Governors and Government System Written by English Travellers in the 19th Century}

\author{
Prof. Dr. Gürsoy ŞAHİN
}

\begin{abstract}
Öz
Bu çalışmanın temel amacı XIX. yüzyılda Türkiye'yi ziyaret eden İngiliz gezginlerin, Osmanlı yönetim sistemi ve yöneticilerin özelliklerine dair izlenimlerini irdelemektir. Bilindiği gibi XIX. yüzyıl seyahatnameler açısından oldukça verimlidir. Zira anılan yüzyılda askeri ve siyasi sebepler, ulaşım imkanlarının iyileşmesi, bilimsel ve romantik akımın etkisiyle çok sayıda seyahatname kaleme alınmıştır. Bu dönemde Osmanlı ülkesine de çok sayıda İngiliz seyyahın geldiği görülmektedir. Gezginlerin seyahatnamelerinde İngiltere'nin Osmanlı Devleti'ne yönelik politikalarından etkilendikleri ve söylemlerini buna göre şekillendirdiklerini belirtmek gereklidir. Gezginlerin Osmanlı ülkesi hakkındaki değerlendirmelerinde çoğu zaman kalıplaşmış önyargılarından kurtulamadıkları da söylenmelidir. Araştırmada XIX. yüzyılın farklı dönemlerinde Osmanlı ülkesine gelen W. Wittman, R. R. Madden, F. Burnaby, C. Fellows, E. J. Davis, W. J. J. Spry gibi çeşitli mesleklerden gezginlerin eserleri incelenmiştir. $\mathrm{Bu}$ seyahatnamelerde Osmanlı yönetim örgütü, yönetim yapısı ve yöneticilerin halkla ilişkilerine dair bazen eleştirel bazen de objektif yorumlar dikkat çekmektedir. Bu anlamda yöneticileri "beceriksiz, yeteneksiz, kaynaklarl verimli kullanılamayan ve tembel" olarak tanımlayan gezginler yanında "kültürlü, akılll, Avrupa'nın politikalarını takip eden ve geniş görüsslü" olarak niteleyen gezginler de bulunmaktadır. Gezginlerin Osmanlı yöneticilerinin karakterleri ve fiziksel özelliklerini de merak ettikleri ve onları tanıma amacı güttükleri anlaşılmaktadır. Kimi gezginler Osmanlı yöneticilerinin "cömert, ulaşılabilir, nazik ve lütufkâr" olduğunu dile getirirken bazıları da "cahil, tutucu ve rüşvetçi" olarak tasvir etmişlerdir.
\end{abstract}

Anahtar Kelimeler: Osmanlı, İngiliz, gezgin, seyahatname, yönetici

Makale Türü: Araştırma

\begin{abstract}
The aim of this study was to examine the impressions of English travellers visiting Turkey in the 19th century about the Ottoman system of government and the characteristics of the Ottoman governors. As known, 19th century was rather rich in terms of travel books because a wide range of travel books were written with the effect of the military and political reasons, the improvement in transportation facilities, and the scientific and romantic movements during the mentioned century. It has been seen that a large number of English travellers came to the Ottoman country as well during this period. It has been necessary to state that the travellers were affected from England's policies for the Ottoman State and shaped their discourses accordingly in their travel books. It should also be reported that the travellers could not usually overcome their stereotyped prejudices in their evaluations about the Ottoman country. In the study, works of travellers such as W. Wittman, R. R. Madden, F. Burnaby, C. Fellows, E. J. Davis, and W. J. J. Spry who were from various occupations and came to the Ottoman country during different periods of the 19th century were examined. In these travel books, sometimes critical and sometimes objective comments about the Ottoman government organisation, government structure, and governors' relations with the public have attracted attention. In this sense, while there were travellers who defined the governors as "unsuccessful, untalented,
\end{abstract}

\footnotetext{
${ }^{1}$ Afyon Kocatepe Üniversitesi, Fen-Edebiyat Fakültesi, gsahin@aku.edu.tr.

Atıf için (to cite): Şahin, G. (2020). XIX. Yüzyılda İngiliz gezginlerin kaleminden Osmanlı yöneticileri ve yönetim sistemi. Afyon Kocatepe Üniversitesi Sosyal Bilimler Dergisi, 22(TBMM’nin 100. Yılı ve Millî İrade Özel Sayısı), 69-91.
} 
whose resources could not be used efficiently, and lazy", there were also other travellers who described them as "intelligent, clever, following the policies of Europe, and broad-minded". It has been understood that the travellers were also curious about the characters and physical features of the Ottoman governors and intended to know them. While some travellers mentioned that the Ottoman governors were "generous, accessible, polite, and beneficent", some others portrayed them as "illiterate, conservative, and briber".

Keywords: Ottoman, English, traveller, travel book, governor

Paper Type: Research

\section{Giriş}

XV. ve XVI. yüzyıllardan itibaren Osmanlı topraklarına çok sayıda seyyahın geldiği bilinmektedir. Bunların gelişlerinin farklı amaçları bulunmaktadır. Osmanlı ülkesine gelen Batılı gezginlerin misyonerlik yapmak, Kudüs'e gitmek, macera yaşamak, ülkeleri hesabına casusluk yapmak, Osmanlı topraklarındaki stratejik bölgelerin haritalarını çıkarmak, faydalı nesneler toplamak ve bilimsel araştırmalar yapmak gibi çeşitli sebeplerle seyahat ettikleri görülmektedir. Keza seyahatleri sırasında el yazmaları, ilaçlar, eski madalyalar ve paralar satın alan, kitabelerin kopyalarını çıkarıp ibadet ve sanat mekanları ile ilgili ölçümler yapan gezginler de bulunmakta idi (Löschburg, 1998, s. 11). Bu gezginlerin seyahatleri sırasında topladıkları bu tür bilgi ve değerlerin bugün için çok kıymetli olduğu muhakkaktır. Ancak seyahatnameleri tarih araştırmalarında kaynak olarak kullanırken temkinli olunmalı ve seyyahların peşin hükümlü olabilecekleri unutulmamalıdır (Burnaby, 2000, s. 184, 207, 243; Spry, 1895, s. 121, Şahin, 2017, s. 23-25). Çünkü bu tür eserlerde günlük hayatta rastlanabilecek problemler alış1lmadık olaylarmış gibi tasvir edilebilmekte, okuyucuların ilgisini çekmek amacıyla çarpıtma ve abartılı bilgi aktarılması ayrıca gezilen yerle ilgili bilgi eksikliği söz konusu olabilmektedir (Bulut, 2002, s. 95; Lewis, 1984, s. 248; Ünlü, 1982, s. 149).

Geçmişten getirilen önyargılar da seyahatnamelerin içeriğini etkileyen sebeplerdendir. Bu anlamda gezginler, çocukluklarından beri dinledikleri çeşitli görüş veya kanaatleri eserlerinde onaylamak zorunda hissetmişlerdir (Kabbani, 1993, s. 10). Bu konudaki bir İspanyol atasözüne göre; "uzun yolculuklara çıkan, kuyruklu yalanlarla eve döner" (Robins, 1999, s. 37). Bu nedenle seyahatnamelerdeki yorum ve bilgiler değerlendirilirken gezginin eğitim ve kültür seviyesi ile eserin yazıldığı dönemin şartları mutlaka göz önünde bulundurulmalıdır. Seyahatnamelerdeki mevcut olumsuzluklara rağmen gezginlerin izlenimleri, bir ülkenin görece entelektüel temsilcilerinin bakış açısını tespit etmek açısından önemlidir. Dolayısıyla eleştirel bir yaklaşımla değerlendirilmek şartıyla seyahatnamelerin tarihi kaynak olarak değerleri tartışma götürmez bir gerçektir.

XIX. yüzyıldan itibaren ulaşım imkanlarının iyileşmesi, askeri ve siyasi sebeplerle gezginlerin seyahatleri daha da artmıştır. Osmanlı ülkesi ile ilgili çok sayıda eserin kaleme alındığı bu dönemdeki seyahatnamelerin içerik açısından oldukça zengin olduğunu söylemek mümkündür. $\mathrm{Bu}$ meyanda anılan yüzyılda Osmanlı ülkesini ziyaret eden İngiliz gezginlerin kaleme aldıkları seyahatnamelerde Osmanlı toplumu, şehirler, ekonomik yapı, gayrimüslimler, sağlık koşulları, yönetim sistemi ve yöneticilerle ilgili dikkat çekici bilgiler bulunmaktadır.

Esasen XVII. yüzyıldan itibaren Osmanlı-İngiliz siyasi ve ticari ilişkilerinin gelişmeye başlamasıyla İngiltere'den Osmanlı ülkesine seyahat eden gezginlerin sayıları artmaya başlamıştır². İngiliz-Osmanlı ilişkileri XVIII. yüzyılın ortalarına kadar daha çok ticari alanda devam ederken, bu tarihten sonra diplomatik alanda da ağırlık kazanmaya başlamıştır. Bilahare Rusya'nın önemli bir güç olarak ortaya çıkması ve Osmanlı Devleti'ne yönelik politikaları sebebiyle 1830'lardan sonra İngiltere, Osmanlı Devleti'nin toprak bütünlügünü korumaya yönelmiştir (Todorova, 2013, ss. 198-199). Osmanlı Devleti'nin zayıf da olsa mevcudiyetini

${ }^{2}$ XIX. yüzyılın sonlarında İstanbul'daki İngiliz elçisi Osmanlı Devleti tarafından "fevkalade itibar ve hürmete mazhar" olarak kabul edilmiştir. Uzunçarşıll, 1949, s. 580. 
devam ettirmesine yönelik bu diplomatik tutum, seyahatnamelerde kendini hissettirmiştir. Keza Osmanlı Devleti'nin içinde bulunduğu ortam, amaçları bir anlamda sömürge faaliyetleri için bilgi toplama olan gezginlere uygun bir zemin hazırlamıştır. Söz konusu şartlar nedeniyle XIX. yüzyılda İngiliz gezginlerin kaleme aldıkları seyahatnamelerin çoğunda politik bir söylemin geliştiği ifade edilmelidir. Anılan dönemde İngiliz gezginlerin seyahatnamelerindeki üslup, İngiltere ile Osmanlı Devleti arasındaki ilişkilerle doğrudan alakalıdır.

\section{Seyyahların Osmanlı Yönetim Sistemi Hakkındaki İzlenimleri}

Osmanlı yönetim sistemi İngiliz gezginlerin ilgisini çeken hususların başında gelir. Osmanlı Devleti'nin bütün kurumlarıyla zirvesini yaşadığı klasik dönemde istisnaları hariç yönetim örgütü oldukça iyi işlemiştir. 1683 Viyana bozgunu, Avrupa'da Hristiyanlığın Türklükten intikam alma zamanının gelmiş olduğunu gösteren bir işaret sayıldığı için Türklere karşı bir kutsal ittifak kurulmuştur. On altı yıl süren savaşlar 1699'da Karlofça Antlaşması ile sona ermiş, Osmanlı ordusunun yeni usullere göre savaşmasının gerekliliği anlaşılmıştır. Bu arada Osmanlı askeri gücünün ciddi derecede zayıfladığı görülmüş ve yüzyıllarca devam eden "düşman üzerindeki Türk kudreti” silinmeye başlamıştır (Uzunçarş1l1, 1983, ss. 585-595). Bu kötü gidişatı düzeltmek amaciyla zaman zaman yenilik faaliyetlerine girişilmişse de kesin bir sonuç alınamamıştır.

Viyana bozgunu sonucu Avrupalıların gözündeki “yenilmez Türk” imajının ortadan kalkmasıyla, Türkler artık "panik yaratıcısı" olmaktan çıkmaya başlamıştır. Ancak bu döneme kadar "zalim Osmanlı" imaj1 Batılıların bilincinde yerleşmiştir (Spohn, 1996, s. 54). Türklerin "cesur, kahraman ve vakur" haline karş1lı yönetim sisteminin "baskıcı ve kötü" olduğu gezginlerin pek çoğunun ortak kanaati idi. Mesela XVIII. yüzyılda Türkiye’ye seyahat eden Giambattista Casti isimli İtalyan gezgin, Osmanlı yönetim sisteminin bir "zulüm ve eziyetler sistemi" olduğunu, hükümdar ve gözde adamlarının, vezir ve valilerin servetlerini gasp ettiklerini ifade etmektedir. Gezgin, bu yöneticilerin maiyetlerindeki memurları soyduklarını, memurların da halkın kanını emdiğini, sonra da bu eziyet ve işkencelerden hükümetin, servet sahiplerinin can ve malına el atmak için bir hak ve bahane olarak yararlandığını belirtmektedir (Öncel, 1969, s. 86). Alman Mareşal Moltke'nin aktardıklarına göre ise "memuriyet satışları" devlet gelirlerinin en büyük kısmını teşkil etmekteydi. İnsanlar zengin olmak için vakit bırakmayacak rakiplerden, zengin olunca da mallarının müsadere edilmesinden korkmaktaydılar. Şehir halkı kendilerini "soymak için" yeni bir paşanın geldiğini önceden haber alır ve ona karşı silahlanırdı. Görüşmeler olur, anlaşmaya varılamazsa savaş çıkar, anlaşma bozulursa isyan çıkardı. Paşa, âyanla anlaşınca bu sefer onların yerine Bâbıâli'den korkmaya başlarlardı. Moltke, bütün bu olumsuzlukları anlattıktan sonra bazı yöneticilerin yönetimde başarı sağladığını da ifade etmektedir (Moltke, 1969, s. 46).

XIX. yüzyılın ilk çeyreğinde Osmanlı ülkesine gelen İngiliz gezgin R. R. Madden ise Osmanlı Devleti'nin içinde bulunduğu finansal krizin yöneticileri etkilediğine vurgu yapmaktadır. O, Türk yöneticilerinin "açgözlü ve doymak bilmez" olduklarını, zavallı köylülerin son parasına kadar ellerinden aldıklarını, ülkenin ekonomik durumunun son beş yılda iyice kötüleştiğini, vilayetlerin peş peşe harap olduğunu, Mora'daki Yunan isyanı ve neticede pek çok adanın elden çıkmasının sultanın gelirini azalttı̆̆ını ve Türk ekonomisine ölümcül darbe vurduğunu bildirmektedir. Gezginin ifadelerine göre hem donanmanın hem de kara ordusunun harcamaları ülkenin hazinesini tüketmiştir. Sultan II. Mahmud'un çabasına rağmen devam eden savaşlar nedeniyle, ülkedeki kötü gidişatın önüne geçilememektedir. Keza yönetim, kanunlar, eski zamanlardan beri devam eden dini siyaset ne zamana uyum sağlamakta ne de devletin sorunlarına çare olabilmektedir (Ahmed Lütfi Efendi, 1999, ss. 15-16; Madden, 1829, ss. 25-26; Sahhâflar Şeyhi, 2000, ss. 53-55).

XIX. yüzyılın ortalarında dönemin siyasi yapısıyla ilgili olarak Türkiye'nin imajı yüzyıl başındakinden farklılaşmıştır. Özellikle II. Mahmud ve Tanzimat Fermanı'nın ilanı sonucunda Osmanlı Devleti ile Avrupalı devletlerin ilişkilerinde yeni bir dönem başlamış, gelişen siyasi 
olaylar “yeni Türk imajını" belirlemiştir. XIX. yüzyılın ilk yarısında uzun süre Osmanlı ülkesinde görev yapan İngiliz elçisi Lord Stratford Canning’e göre sürekli övülecek özelliklerine tanık olduğu Türklerin iyi yönetildiği takdirde bütün büyük devletlere karşı gücünü göstermesinin mümkün olacağını bildirmektedir. Ancak ona göre idari mekanizma tepeden tırnağa kötüdür. Osmanlı yöneticileri nasıl bir çıkmazın içinde olduklarını bilmekte ama düzeltmek için ne cesaretleri ne de yetenekleri bulunmaktadır. Bu zorlukların üstesinden gelmeyi düşünenler ise halkın önyargılarıyla yapılması gereken yenilikleri nasıl bağdaştıracaklarını bilememektedir. Canning, halkın desteği olmadan da bir iş yapmanın imkansız olduğunu bildirmektedir (Poole, 1999, ss. 26, 87).

İngiliz arkeolog Ramsay; Türklerin, Anadolu'da bulunan her kurumu yıktıklarını fakat yerine yenisini kurmadıklarını, bunun bir hata olduğunu, bu şekilde Roma İmparatorluğu'nun idare mekanizmasının ortadan kalktığını, memleketteki toplulukların eğitim ve öğretiminin bozulduğunu, Anadolu'ya göçebe hayatın iptidailiğinin geri geldiğini, Osmanlı Devleti'nin “yıkılmış bir Roma'dan kalan birkaç müessese üzerinde" idare edildiğini, Anadolu'da karşılaşılan hukuk ve idare mekanizmalarının görünüş olarak Müslüman olmakla beraber aslında Anadolu'nun kendisine has geleneksel yapısından kaynaklı olduğunu iddia etmektedir (Uzmen, 1969a, s. 39-45). Diğer birçok gezginde olduğu gibi Ramsay'ın da geçmişe yönelik önyargılarından kolaylıkla sıyrılamadığı görülmektedir. Zira Ramsay bir arkeolog olduğu için Roma dönemini öncelemiş Osmanlı Devleti'ni Roma mirasını yıkan bir yapı olarak karakterize etmiştir. Türklerin göçebe kültürü temsil ettiği önyargısıyla Türklere ait ince bir yönetim anlayışı, keza kültür ve sanat anlayışını yok saymıştır. Oysa dikkatle incelendiğinde Osmanlı Devleti'nin yönetim ve teşkilat yapısında, Roma ve Selçuklu izlerini görmek mümkündür (Ortaylı, 2006, ss. 44-46).

Sir Charles Eliot da Türklerin ezeli ve ebedi göçebeliğinden dem vurarak, Türklerin "yüzyıllardır işgal ettikleri Avrupa'da halen yabancı" olduklarını, ülkelerin kaynaklarını kullandıklarını fakat bu ülkelere hiçbir katkıda bulunmadıklarını, kent hayatına, yerleşik yaşama bir türlü ayak uyduramadıklarını ifade etmektedir (B. Lewis, 1984, s. 262). Ancak gezginlerin bu konuda yanılgıya düştükleri, bahsi geçen pek çok teşkilatın köklerinin Selçuklu veya İslam öncesi Türk devletlerine dayandığı, ayrıca Türklerin medeniyete olan katkılarının yapılan araştırmalarla ortaya konulduğu ifade edilmelidir (Babacan, 2016, s. 603; Gölen, 2016, s. 863; Karaman ve Tümtaş, 2016, s. 469; Köprülü, 1986, ss. 1-268; Ortaylı, 2006, s. 46; Temizer, 2016, s. 1343; Ünlü, 2016, s. 443).

Söz konusu eserlerde Doğuluların özlerinde iyi özelliklere sahip olduğunu fakat idarecilerin baskıcı yönetimleri, gaddarlıkları ve zulümleri nedeniyle kalkınamadıkları, ancak aydın Batılı yönetimler altında Doğulu halkların muazzam bir refaha kavuşacakları ifade edilmektedir (Bulut, 2002, s. 25). Gezginler, Osmanlı yöneticilerinin despotik ve keyfi özellikleri yanında çevrelerinde olup bitenlerden habersiz yaşadıklarını, yöneticilerin sınırsız eğlencelerden başka hiçbir şey yapmadıklarını dile getirmektedir (Başkan, 1997, s. 29; Kabbani, 1993, s. 29).

Görüleceği üzere XIX. yüzyılda Anadolu'ya gelen gezginler tarafından daha çok devletin yönetim sistemindeki bozukluklar gündeme getirilmekte idi. Bu yüzyılda Avrupa toplumunda, Osmanlı yöneticileri hakkında olumsuz bir algı oluşmuştu (Bulut, 2002, s. 95). Bu yapılırken bir anlamda Osmanlı Devleti'nin hâkim olduğu bölgelerdeki meşruiyeti tartışmaya açılmakta, keza XIX. yüzyıl sömürgeci devletlerinin müdahalelerine zemin hazırlanmaktaydı (Başkan, 1997, s. 29; Bulut, 2002, s. 106).

\subsection{Merkezi Yönetim}

Gezginler merkezi yönetimle ilgili izlenimlerini aktarırken Osmanlı'da padişahın gücünün mutlak olduğunu, bu gücü sınırlandıracak hiçbir kurumun bulunmadığını, padişahlara kutsiyet atfedildiğini sıklıkla vurgulamışlardır (Tott, ty, ss. 31, 63, 94). Padişahların kullandıkları unvanların bu kutsiyeti perçinlediği, mesela "Tanrının yeryüzündeki gölgesi", "güneş ve ayın kardeşi" ya da "dünyadaki tüm taçların vericisi" gibi sıfatların hükümdara verilen gücü 
gösterdiğini dile getirmişlerdir. Ancak gezginlere göre Türklerdeki kutsiyet Roma'dan farklıdır. Onlar hükümdarları için tapınaklar ve sunaklar inşa etmezler. Örneğin XVII. yüzyılda Osmanlı ülkesinde bulunan Paul Rycaut'a göre eski Roma' da olduğu gibi Türk hükümdarı adına tapınaklar ve sunaklar inşa edilmemekte ancak hükümdara bir kutsiyet atfedilmektedir. Ona göre Osmanlı'da halk, hükümdara karşı kul vaziyetindedir. Devlet adamları hükümdara o derece bağlıdır ki bir gün onun emriyle ölmeyi bile seve seve kabul ederler (Erhan, 1996, s. 50).

XIX. yüzyıl gezginlerinden W. Spry da sultanın, Tanrının yeryüzündeki gölgesi olduğuna dair bilgiler vermektedir (Spry, 1895, s. 78). Gezgin R. R. Madden, Türklerin sultanlarına son derece bağlı olduklarını ve halkın bu şevkinin ve coşkunluğunun savaşlarda hükümdarlar tarafından s1klıkla avantaj olarak kullanıldığını bildirmektedir (Madden, 1829, s. 27-28). Gezginlerin ifade ettikleri bu anlayış aslında ulû'l-emre itaat anlayışından kaynaklanmaktadır. Bu anlayışa göre halife sultana ve onun askerî ve sivil memurlarına, kısaca devletin emirlerine itaat etmek devleti ayakta tutmak için bir zorunluluktur. İtaatsizlik devleti ortadan kaldıracağından Müslümanlar dinî inançları ve dünyevi ihtiyaçları gereği halife-sultana itaat etmeyi kutsal görev bilmiştir (Kodaman, 2007, s. 3).

XIX. yüzyılın başlarında Türkiye'ye gelen gezgin W. Wittman da Türk yönetim yapısı ile ilgili bilgiler aktarmıştır. O, vezirlerin diğer önemli görevliler gibi sultanın onurunu korumak için uğraştıklarına dikkat çekmiştir. Wittman'ın bildirdiğine göre merkezi yönetimde bostancılar da önemli görevler icra etmektedir. Gezgin, bostancıların yöneticilerine bostancıbaşı adı verildiğini ve önemli görevlerin onların ellerinde olduğunu bildirmiştir. İstanbul'da çok sayıda bostancı bulunmakta olup bunlar sultanı korumakla görevlidirler. Bostancıların teşrifat için de önemli oldukları, geçit törenleri sırasında sultanın saltanat kayığını yönettiklerini ifade etmiştir. Bostancıbaşıların yetki alanı sadece harem dairesindeki sivillerle sınırlı değildir, Boğaziçi’nin kıyısındaki köyler de onun yetki alanı içine girmektedir (Wittman, 1803, s. 244).

XIX. yüzyılın başlarında siyasi amaçlarla Türkler ve Osmanlı yönetimi aleyhine yazılar yazanlar da bulunmaktaydı. Bu yazılar haliyle Osmanlı yöneticilerinin Avrupa'da olduğundan farklı tanınmasına sebep olmakta idi. Mesela İngiliz subay A. Slade, Sultan II. Mahmud'u "diktatör bir yönetici" olarak tanımlar. Ona göre Sultan II. Mahmud'un "zorbalığına karşı" ayanlar ve ulema kısmen kontrol aracı olarak çalışmaktadır. Bu sebepten sultan, merkezileşmenin bir gereği olarak ilk önce bu üç organı ortadan kaldırmak veya zayıflatmak için çaba göstermiştir (Slade, 1945, s. x). Ancak Slade'nin bir yandan "Türk zorbalı̆̆ı" olarak bilinen kötülükleri, Yeniçerileri ve ulemayı savunduğu bir yandan ise eski sistemi eleştirdiği anlaşılmaktadır (Lewis, 1984, s. 255-257). Bu dönemde esasen Yunan meselesine inanmadığı halde Avrupa'nın seçkin üniversitelerinde profesörlük elde edebilmek için Osmanlı yöneticilerini eleştiren gezginler de mevcut idi (Ünlü, 1988, s. 89).

İngilizler gezginler yanında farklı milletlerden isimler de Osmanlı yöneticileriyle ilgili gözlemlerini aktarmışlardır. Bunlardan birisi XIX. yüzyılın sonlarına doğru Türkiye'ye gelen Amerikalı gazeteci, yazar ve diplomat S. G. W. Benjamin'dir. Gezginin, Sultan Abdülaziz ile ilgili fikirleri dikkat çekicidir. S. G. W. Benjamin, sultanı "asrın en müsrif adamı" olarak tanımlarken onun kabiliyetli, karakteri kuvvetli, yükselme ve ileri gitme arzusunda olduğunu bildirir. XIX. yüzyıl şartlarında Sultan Abdülaziz'in büyük bir güç oluşturamayacağını ifade eden gezgin sözlerine şu şekilde devam etmiştir; "Hristiyan aleminin medeniyet ve askerlik bakımından Tatar ırkları ile aynı seviyede bulunduğu bir zamanda yaşamış olsaydı, muzaffer Yeniçerilerini Viyana surlarının önüne kadar gönderir ve birçok Hristiyan kızının yanaklarını isminin dehşetiyle soldururdu”. S. G. W. Benjamin Türk milletinin yavaş yavaş kendi mezarı içine yuvarlandığını söyleyip, milletin karakterini beğenmese de varlığının devamını istemese de "alnında ölüm emarelerini" gördüğü ırkın can çekişmesi karşısında Türklere sempati duymamakla katı kalplilik edilmiş olunacağını söylemektedir. O, Türk halkının bu son zamanlarındaki mülayimliğini, bu kadar ince bir güzelliğe sahip olmasını, sonbaharın yaklaşmasıyla "sessiz tepeler üzerine yaslanan endişeli bir sevimlilik” olarak tanımlamıştır (Benjamin, 1959, ss. 112-113). 
Gezginlerin dikkatini çeken hususlardan birisi de protokol kuralları idi. Polonyalı Edward Raczynski, Sultan II. Mahmud'dan ve yönetim örgütünün özelliklerinden bahsederken, saray erkânı olan çok sayıda Yeniçerinin, İstanbul'daki garnizon kıtalarına bağlı subayların, bir alay bostancı, baltacı ve sarayın diğer askerlerinin padişahı takip ettiğini anlatır. Saray erkanı arasında kızlarağasını da gördüğünü bildiren gezgin, onu zavallı olarak nitelendirmekte ve kapıağası veya akağaların başı gibi haremindeki bir sürü kadını kollamakla görevli olduğunu belirtmektedir. Sarayın geleneklerine göre bu kadar çok kadın, böyle bir adamın eline birakılmakta idi. Kızlarağasına sadece bir devlet hizmetlisi gözüyle bakıldığı için o da kuralların dışına çıkmıyordu. Gezgin, tahminlerine göre Türkiye dışında başka hiçbir yerde protokol kurallarına bu kadar sıkı uyulmadığını dile getirmiştir. Padişahın da Avrupalı imparatorlar gibi protokolün düzenine uyduğunu, bu bakımdan padişahın söylemesi ya da yapması gereken şeyleri tayin eden günlük kaidelerin bulunduğunu, Bâbiâli'deki törenleri organize edenlerin şefine "teşrifatçı efendi" denildiğini belirtmektedir (Raczynski, 1980, ss. 70, 184-185).

\subsection{Liyakat ve Terfi Sistemi}

Osmanlı Devleti'ndeki liyakat ve terfi sistemi eskiden beri gezginlerin dikkatini çeken ve beğeni ile bahsettikleri hususlardandır. Bu anlamda XVI. yüzyılda Osmanlı ülkesinde bulunan Avusturyalı diplomat Ogier Ghiselin de Busbecq'e göre Türkiye'de tembel, pısırık ve kötü niyetli kişilerin yükselme yolları kapalıdır. Ona göre Türklerin giriştikleri her işte başarı kazanmalarının ve gün geçtikçe devletin sınırlarını daha da genişletmelerinin sebebi liyakati esas almalarıdır (Busbecq, ty, ss. 32-33, 63-64). Aynı anlamda bilgilere farklı gezginlerde de rastlanmaktadır. Mesela XIX. yüzyılın ilk çeyreğinde Türkiye'yi görüp izlenimlerini aktaran İngiliz A. Slade, Türkiye'de kölelerin büyük talih ve ikballerinin olabileceğini, bunun pek çok örneğinin bulunduğunu, ülkede kölelerin vaziyetlerinin utanma ve kederle değil iftihar ve sevinçle kabul edildiğini ifade etmektedir (Slade, 1945, s. 131). Keza İngiliz gezgin R. R. Madden gerek ordudaki gerekse yönetimdeki memurların sarayda gerekli eğitimden geçirildiklerini, bu kişilerin Türkçeyi ve İslam dinini öğrendiklerini, insanların kölelikten veya en kötü durumlardan Bakan seviyesine kadar çıkabileceğini bildirmektedir (Madden, 1829, s. 56). XIX. yüzyılın ortalarında Türkiye'ye gelen Sir James Porter de asil bir aileden gelmenin yükselmek için yetmediğini, kulübede yetişmiş birisinin de yüksek mevkilere gelebilme şansı yani sosyal adalet olduğunu bildirmektedir (Celkan, 1984, s. 420).

Gezgin E. Raczynski ise İstanbul'da "rical" denilen ve yüksek sınıfı meydana getiren bir zümre bulunduğunu anlatırken bunların sadrazamlar, kaptan paşalar ve devletin diğer ileri gelen kimseleri olduğunu fakat hiçbirinin belirli bir soyadı olmadığını bildirmektedir. O, kabiliyeti veya zenginliği ile tanınan bir kimsenin soyundan gelen ailelerin isimlerinin sonuna sadece "-oğlu" kelimesinin getirildiğini bildirmektedir. Hatta meşhur Sadrazam Köprülü’nün torununa dört ya da beş nesil geçmesine rağmen hala Köprülüoğlu denildiğini bildirmektedir. Gezgine göre ataların hatırasına karşı gösterilen bu his çok yücedir. Aşağı tabakadan olan kimselerin yüksek mevkilere çıktıkları zaman asıllarını saklamaya çalışmamaları, onların saygıya değer sadeliklerini göstermektedir. Bu sadelik meslek isimlerini adlarıyla birleştirecek kadar ileridir. Mesela gezgin tanıştığı çok bilgili, kültürlü ve iyi derecede Fransızca bilen bir kişinin babası tarakçılık yaptığı için isminin "Şânî-zâde" olduğunu ve bu şahsın da çok önemli bir mevkide bulunduğunu ifade etmektedir (Raczynski, 1980, ss. 70, 184-185).

Pek çok gezgin terfi sisteminden beğeni ile bahsederken İngiliz gezgin F. Burnaby, Osmanlı'da terfi sisteminin hakkaniyet çerçevesinde işlemediğini ifade etmekte ve yaşadığı bir örneği anlatmaktadır. Gezgin, Erzincan'daki kışlayı bir yüzbaşı ile gezdiklerini anlatırken, bu yüzbaşının terfi etmeyi heyecanla beklediğini ifade etmektedir. Yüzbaşı evlenmek istediğini ancak maaşının çok az olması sebebiyle bir eşe bakmaya yetmeyeceğini, bunun için öncelikle binbaşı rütbesine yükselmesinin gerektiğini dile getirmiştir. Burnaby'yi asıl şaşırtan husus ise yüzbaşının Erzurum'daki paşayı gördüğü takdirde kendisi için onunla konuşup terfi etmesini önerip önermeyeceğini sormasıdır. Gezgin, Türk ordusuna mensup olamadığını söylemesine karşılık yüzbaşı yine de cebinden çıkardığı bir kağıda ismini yazarak Burnaby'e vermiştir 
(Burnaby, 2000, ss. 253-254). Gezginlerin beğeni ile bahsettikleri terfi sistemi hakkında Burnaby'nin bu ifadelerinin münferit bir hadise olduğunu söylemek gereklidir. Zira yüzbaş1 rütbesindeki bir askerin terfiinin hangi şartlarda mümkün olduğu açıktır.

Seyyahlar kaleme aldıkları eserlerinde Batı düşüncesini benimsemiş olan Osmanlı yöneticilerden övgüyle bahsetmişlerdir. Örneğin C. Fellows, Aydın Valisi Tahir Paşa hakkında olumlu düşüncelerini eserinde dile getirmiştir. Bu meyanda henüz Aydın'a gitmeden İzmir'de Vali hakkında olumlu sözler duymaya başladığını belirtmektedir. Kendisini tanıdığında ise Tahir Paşa'nın antik heykelleri koruyan çok güçlü, nüfuzlu ve Osmanlı ülkesindeki insanlara göre çok aydın bir yapıda olduğunu anlamıştır. C. Fellows onu "mükemmel bir arkadaş" olarak nitelendirmiştir. Paşa'nın İtalyanca konuşabildiğini, şampanya ve sigara içtiğini, dans ettiğini ve beyaz eldiven kullandığını bildirmiştir (Fellows, 1852, s. 68, 243-244). İfadelerden anlaşılacağ üzere Fellows, Tahir Paşa'yı kendine yapı olarak yakın hissetmiş, Batılı yaşam tarzını benimsemesinden dolayı onu ayrı bir yere koymuştur.

Benzer düşünceler E. J. Davis tarafından da dile getirilmiştir. O, Adana Valisi Halil Paşa'nın çalışmalarını son derece başarılı bulduğunu eserinde ifade etmiştir. Gezgin, Halil Paşa'nın uzun süre Malta'da yaşadığını, düşünce dünyasını zenginleştirerek Batılı fikirlere sahip başarılı bir entelektüel olduğunu vurgulamıştır. Valinin Adana'yı Malta gibi geliştirmeye karar verdiğini bildirmiştir. Halil Paşa'nın çalışmaları sayesinde şehir oldukça gelişmiştir. Davis, Halil Paşa'nın bazı insanlara karşı gelerek şehri belirli bir plana göre inşa etmeye başladığını aktarmıştır. Ancak Halil Paşa'dan sonra Adana'ya gelen yöneticilerin bu adımları devam ettirmemeleri nedeniyle eski düzene geri dönüldügü ifade edilmiştir (Davis, 1879, ss. 55-56).

XIX. yüzyılın sonlarında Türkiye’ye gelen İngiliz arkeolog Sir Ramsay ise hükümet ve memurlar hakkındaki izlenimlerini aktarırken, gerek Sultan II. Mahmud'un gerekse ondan önceki padişahların kanunlarının iyi ve hakkaniyet dairesinde hazırlandığını belirtmektedir. Keza Türklerle Hristiyanlar arasındaki ilişkilerin makul bir şekilde sürdüğünü de dile getirmiştir. Fakat gezgine göre bu kanunların uygulanışı istendiği şekilde değildir. Bunun sebepleri arasında Türk memurlarının kanunları uygulama imkanından mahrum olması, memurların maaşlarının gülünç derece yetersiz olması ve bu maaşların daima gecikmesi sayılabilir. Üstelik memur olmak için rüşvet vermiş kişilerin rüşvet almaya zorlandığ1, bu sistem içerisinde herkesin memurların durumunu bildiği ve bu şekilde hareket ettiği dile getirilmiştir. Bunun yanında gezginin iddialarına göre, "Türkler karakter itibariyle tembel olduklarından bir memur veya subayın katlanması gereken sıkıntılardan kaçınmayı tercih etmektedirler". Ramsay, Türk memurlarının yetersiz olduklarını, kendilerine gelen evrakı dahi okuyamadıkları için başkalarına okuttuklarını, evrakı okuyabilen memurların ise bunu herkesin görebileceği şekilde yaptığını bildirmektedir. O, hükümet işlerinin kırtasiye ile ilgili yönlerini yürütmek için Türklerin daima Rum ve Ermeni memurlara muhtaç olduklarını, diğer taraftan memur yetiştirmek için gerekli mekanizmanın mevcut bulunmadığını, kabiliyetli Türk memurların ise aslında Arnavut veya Çerkez olduğunu, Türk gençlerinin yetiştirilmesi amacıyla okulların açılması hususunda bazı padişahların gayret sarf ettiklerini fakat başarılı olamadıklarını dile getirmiştir (Uzmen, 1969a, ss. 38-45).

\subsection{Yönetimde Kuralsızlık ve Keyfi Uygulamalar}

Gezginlere göre Osmanlı ülkesinde yönetim sisteminin en sorunlu taraflarından birisi kuralsızlık ve keyfi uygulamalardır. Bu durum gezginler tarafindan genellikle "halkın ezildiği, soyulduğu ve gelir kaynağl olarak görülddüğü" şeklinde yorumlanmıştır. Mesela Baron De Tott, paşaların halktan topladıkları servetleri ile hayatlarını teminat altına aldıklarını anlatmaktadır. O, Sultan III. Osman zamanında muhtemel yangınların önüne geçmek ve söndürme çalışmalarının daha kolay yapılmasını sağlamak için İstanbul'da bazı sokakların genişletilmek istendiğini, bunun üzerine ev sahiplerinin bir araya gelerek atadan, babalarından kalan ev ve arsaların sokak yapılmasına izin vermeyeceklerini bildirdiklerini ifade etmektedir (Tott, ty, ss. 31, 63, 94). Tott, ödeme yapılması gerektiği halde sadece emir veren fakat üstesinden gelinmesi kolay bir direnme 
karşısında geri adım atan bu yönetim anlayışını keyfi yönetimlerin uygunsuzluğuna delil olarak göstermektedir (Tott, ty, ss. 20-21, 247).

İngiliz elçisi Canning de Türk yönetim yapısındaki keyfiliğe dikkat çekmiştir. O, “Türkiye'de sistem, usul diye bir şey yoktur. Herkes elindeki imkanlarına göre ne koparabilirse koparır, kendinden zayıfi ezer, kendinden güçlü olanlar karşısında boyun eğer" ifadelerini kullanmaktadır (Poole, 1999, s. 93). Keza İngiliz gezgin F. Burnaby, yöneticilerin bu anlamdaki özelliklerinden bahsederken birbiriyle iyi anlaşamayan yöneticilerin keyfi davranışlarıyla ilgili duyduğu bir rivayeti şöyle anlatmaktadır. Sadrazam, Sultan Abdülaziz ile boğaz kenarında yürüyüş̧e çıktığı esnada Sivas Valisi İshak Paşa'ya ait güzel bir kayık sarayın yakınlarında demirli imiş. Padişah kayığı çok beğenince, İshak Paşa'yı pek sevmeyen sadrazam, kayığın İshak Paşa'ya ait olduğunu ancak buraya padişahın emrine sunmak üzere gönderdiğini bildirmiştir. Padişah, paşaya yazı göndererek kayığı memnuniyetle kabul ettiğini ve teşekkür ettiğini bildirmiştir. İshak Paşa'nın haberi olmadan gerçekleşen bu hadise padişahın mektubu alınınca anlaşılmıştır.

Benzer bir örnek yine İshak Paşa ile ilgilidir. Savaş için bir kampanya başlatılmış, İshak Paşa Sivas halkından on bin lira toplamıştır. Paşa, bu parayı sadrazama göndermiş ancak para halk adına değil de İshak Paşa'nın bağışı gibi kabul edilmiştir. Hükümet, ayrıca Sivas halkından toplanan yardımı da talep etmiştir. Bunun üzerine vali, bu durumdan hoşlanmamakla birlikte tekrar on bin lira daha göndermiştir (Burnaby, 2000, s. 184). Buradan da anlaş1lacağı üzere özellikle imparatorluğun son yüzyılında keyfiliğin yönetim kademelerinde ve yöneticiler arasında oldukça yaygınlaştığına dair görüşler gezginler tarafından dile getirilmiştir.

Gezginlerin dikkatini çeken ve eserlerinde yer verdikleri bir diğer husus ise Türk yöneticilerin kısa süre içinde görevlerinden alınma, mallarına el konulma hatta hayatlarının da sona erdirilme ihtimalidir (Slade, 1945, s. 118). Mesela Burnaby'e göre Elazığ'da sohbet ettiği bir kaymakam, her an görevinden alınma ihtimalinin bulunduğundan, yaptığı bütün işlerin kendisinden sonra gelen yönetici tarafından bozulma olasılığının oldukça yüksek olduğundan bahsedip bu sebeple halka hizmet götürme şevkinin kalmadığını ifade etmiştir. Verilen maaşın geçinmeye yetmediğini bildiren kaymakam, bu yüzden rüşvet olaylarının oldukça fazla olduğunu dile getirmiştir (Burnaby, 2000, s. 234).

Gezginler yöneticilerin israfa kaçan harcamalarının olduğundan da bahsetmişlerdir. Örneğin İngiliz gezgin George William Frederick Howard'a göre Topkapı Sarayı padişahlar için emsalsiz bir saraydır. Ancak yöneticiler bununla yetinmek istememişlerdir. Padişahlar emsalsiz bir şekilde inşa edilen Topkapı Sarayı ile yetinmeyip o sarayı daha da güzelleştirmek için çalışmak yerine kendilerine yeni bir saray yaptırmışlardır. Howard'a göre bu durum "Türk milletinin kaderinin ıstırabı" olmakta ve birçok gereksiz masraf çıkmaktadır (Howard, 1978, s. 58). Gezginlerin Osmanlı yönetim sistemini yeterince bilmemeleri, yönetimde bir kuralın olmadığı veya her yerin keyfi olarak yönetildiği algısına kapılmalarına sebep olmaktadır.

\section{Gezginlerin Osmanlı Yöneticilerinin Özellikleri Hakkındaki İzlenimleri}

Türkiye'ye gelen gezginler genel olarak Osmanlı padişahının ve yöneticilerin karakteristik özelliklerini merak etmişler ve onları yakından tanımayı amaç edinmişlerdir. $\mathrm{Bu}$ anlamda kimi gezginler Osmanlı yöneticilerinin "cömert, ulaşılabilir, nazik ve lütufkâr" olduğunu dile getirirken bazıları da "cahil, tutucu ve rüşvetçi" olarak tasvir etmişlerdir.

Gezginler genel olarak Türk sultanını ve yöneticileri "Doğululara mahsus muhteşem klyafetleri içinde ve son derece süslü bir oda içinde" göreceklerini düşünmüşlerdir. Kimi gezginler hayallerindeki bu manzara ile karşılaşmışlar kimileri ise bu manzarayı göremedikleri için hayal kırıklığı yaşamışlardır (Wittman, 1803, s. 7-8, 45-46). Gezginler için padişahı görmek gezilerinin en önemli kazanımlarından birisidir. Padişahı, hazineyi, Dolmabahçe ve Beylerbeyi Saraylarını görebilenler kendilerini oldukça şanslı saymışlardır. Bazı gezginler aracılar bularak buraları görmek için çaba harcamışlardır. Mesela Eski Düyûn-1 Umumiye Reisi İngiliz Vincent Caillard'ın eşi ile dostlarından Sir Charles ve Lady Dilke'nin hazineyi, Dolmabahçe ve 
Beylerbeyi Saraylarını ziyaretlerine aracılık ettiği ve padişahın huzuruna kabullerinden dolayı Agop Paşa'ya teşekkür mektubu gönderdikleri belgelerden anlaşılmaktadır (BOA, Y.EE., 108/29).

Gezginler padişahları görmek için daha ziyade cuma selamlığına katılmışlardır. Padişahın ve yöneticilerin fiziksel özelliklerini merak eden gezginler için padişahın da katıldığ 1 cuma selamlığı kaçırılmaz bir firsattır. Gezginler bu töreni görmek için özel olarak İstanbul'a gelmişlerdir. Mesela 1898 yılının Kasım ayında İstanbul'a gelen altmıştan fazla İngiliz gezginin cuma günü selamlık merasimini ve padişahı görmek için izin istediği görülmektedir (BOA, Y.PRK.TŞF., 5/61). Sadece İngilizler değil çoğunluğu Alman tüccar ve ailelerinden ibaret gezginlerin Bükreş’ten İstanbul'a selamlık resmini ve şehri görmek için gelmek üzere izin talebinde bulunmuşlardır (BOA, Y.PRK.EŞA., 6/71). Aynı şekilde sonraki dönemlerde de gezginlerin selamlık merasimine ilgi gösterdikleri, mesela 1900 yılında da sayı olarak yüzü aşkın gezginin selamlı merasimine katılmak üzere İstanbul'a geldiği arşiv belgelerinden anlaşılmaktadır (BOA, Y.PRK.ZB., 25/91). Seyyahların cuma selamlığına katılmak için yoğun istekte bulunmaları bu hususta bazı tedbirleri gerekli kılmıştır. Bu meyanda selamlık merasimini görmek için İstanbul'a gelmek isteyen gezginlere sefaretlerce kabul varakası verilmemesi konusunda ilgililer uyarılmıştır (BOA, Y.PRK.EŞA., 38/24).

E. Chishull, padişahın cuma günü saraydan cuma selamlığına gitmesini anlatırken önde bir çavuş bulunduğunu, çavuşların arkasında yedekte götürülen altı adet at, daha arkada ise külahları parlak gümüşlerle süslü ve cepkenleri sırma işli solakların, padişahın iki yanında başlarında çok güzel beyaz deve kuşu tüyünden sorguçlar taşıyan çorbacıların yürüdüğünü, padişahın atını, silahtar ağasının ve kızlar ağasının görkemli atlarının takip ettiğini bildirmektedir. Gezgine göre "Imparator Mehmed'in oğlu, kara ve denizlerin güçlü sultanı, sultan oğlu sultan, Sultan Mustafa Han" unvanlı padişah, kısa boylu, geniş omuzlu ve şişman, yavan sarı tombul yüzlü, yassı burunlu, dar alınlı, dikkat çekecek kadar uzun ve tombul çeneli bir kişidir (Chishull, 1993, ss. 87, 89, 91). XVIII. yüzyılın başında Türkiye'de bulunan İngiliz din adamı E. Chishull, sadrazamı ziyaretlerini anlattıktan sonra onun fiziksel özelliklerini tarif eder. Chishull'un bildirdiğine göre sadrazam altmış yaşlarında, kısa boylu halim görünüşlüdür. Tören esnasında resmî bir başlık olan ve törende hazır bulunanlar şerefine giyilen selîmî bir sarık sarmışlardır. Bu tip sarık, şeker kalıbı biçiminde, dört tarafından sıkıca sarılıdır ve altta eğik bir sırma şeridi vardır. Yine gezginin bildirdiğine göre İngiliz heyetine hediye edilen kaftanlarla divandaki nazırların giysileri aynı biçimdedir. Kaftanların kumaşları ipek ve grogandan, kürkleriyse samurdandır. Sarığa "mücevveze" denilmekte olup padişah sarığı ile sıradan ağaların sarıkları arasında fark yoktur. Padişah sarı̆ğında yalnız kül renkli dalgalı üç kıymetli siyah küçük tüy bulunmakta ki bu tüyler Moskova'da yaşayan ve nadir rastlanan "arguron" kuşlarının kanat uçlarından temin edilmektedir (Chishull, 1993, ss. 87-91).

1853 'te Osmanlı topraklarına gelen gezgin Howard da padişahın bir cuma günü namaz için bir camiye gittiğine şahit olmuş ve bundan oldukça etkilenmiştir. $\mathrm{O}$, saltanat kayığının muhteşemliğinden söz etmiş ve dört adet büyük ve üç adet yaldızlı kayıktan meydana gelen padişah konvoyunda, padişahın çok görkemli bir tentenin altında oturduğunu ifade etmiştir. Kayıkta yirmi iki kürekçinin bulunduğunu ve hisardaki diğer Türk gemilerinden selam seslerinin duyulduğunu anlatan gezgin, padişahı görmek için çok az kişinin dışarı çıktığını fakat buna anlam veremediğini belirtmiştir. "İngiltere'de Kraliçe Victoria kayıkla Times Nehrinde gezintiye çıksa durum ne kadar farklı olurdu" ifadelerini kullanmıştır (Howard, 1978, ss. 29-30).

Gezgin W. Wittman da padişahı yakından gören isimlerden biridir. O, Sultan III. Selim hakkında bilgi verirken onun Sarayburnu'na çok yakın gösterişli ve görkemli bir sarayda oturduğunu, çevresinin muhafizlar, hükümet ve maiyet memurları ile çevrelendiğini ve hepsinin çok ağır ve zengin elbiseler giydiklerini bildirmektedir. W. Wittman, Sultan III. Selim'in çelebi, nazik ve lütufkâr bir karaktere sahip olduğunu, fiziksel özelliklerinin uyumlu ve orantılı olduğunu dile getirmiş̧ir (Wittman, 1803, ss. 7-8, 45-46). 
XIX. yüzyılın ilk çeyreğinde Türkiye’ye gelen Sir Adolphus Slade de cuma selamlığında sultanı gördüğünden bahsetmiştir. O, Sultan II. Mahmud'u gördügünde sırtında mavi askeri bir setre, harmani, ayaklarında Wellington tarzı çizme ve çelik mahmuzları bulunduğunu, fesindeki pırlantalı çelenkten başka üstünde süs görünmediğini bildirip onun sade giyinişine şaşırmıştır (Slade, 1945, s. 77). Sultan II. Mahmud'u cuma selamlığında gören gezgin Raczynski ise sultanın fiziksel özelliklerini anlatırken onun orta boylu, dolgun yüzlü, keskin bakışlı, sert huylu olduğunu ifade etmektedir (Raczynski, 1980, s. 70). Sultan II. Mahmud'u cirit oyunu sirasında gören gezgin R. R. Madden ise sultanın muhteşem göründüğünü, parıltılı kıyafetler giyen siyah ve beyaz kölelerin sultanı çevrelediğini bildirdikten sonra sultanın yaklaşık kırk dört yaşlarında, görkemli, soylu, uzun siyah sakallarıyla ciddi görünümlü ve hiç gevşeklik göstermeyen, siyah gözlü, hiç gülümsemeyen bir kişi olduğunu bildirmektedir (Madden, 1829, s. 73). Miss J. Pardoe ise 1835 'te İstanbul'da bir Kurban Bayramı'nda Sultan II. Mahmud'u gördüğünü bildirmektedir. Gezgin, padişahı "soylu çehreli, zarif giyinmiş, atının üzerinde bir centilmen tavrlyla oturan ve bakışlarında kesin bir yücelik olan bir adam" olarak tasvir etmektedir (Pardoe, 1997, s. 63).

1840 y1lında Türkiye'de bulunan gezgin C. Fellows, seyahatinde İstanbul'da bulunduğu günlerle ilgili bilgiler verirken, Sultan Abdülmecid hakkındaki izlenimlerini eserinde aktarmaktadır. Onun bildirdiğine göre sultan gösterişli kıyafetler ve düz mavi frak giymekte, özel günlerde kendisinin övüleceği daha gösterişli kıyafetleri tercih etmekte, sarık sarmayıp kırmızı fes takmaktadır (Fellows, 1852, ss. 68, 243-244).

XIX. yüzyılın sonlarında Türkiye'de bulunan Dorina Neave ise II. Abdülhamid'in kişisel özelliklerine eserinde yer vermiştir. Onun verdiği bilgilere göre Sultan II. Abdülhamid, postanelere verilen telgrafları kontrol eder, erken kalkar, kıyafetine özen gösterir, sakalını kına ile boyar, yumurta, süt, meyve ve bisküviden ibaret kahvaltı yapardı. Marangozlukla uğraşmaktan zevk duyardı. Haremi kalabalık olup kendisi tahttan indirildiğinde iki yüzden fazla kadın Topkap1 Sarayı'na nakledilmiş ve akrabalarına kadınların alınması için haber gönderilmiştir. Ayrıca Yıldız Sarayı'ndaki özel tiyatroya gelip gittiği belli olmasın diye kafes arkasında kalmıştır (Neave, 1978, s. 30-33).

Gezginler padişahlar dışında diğer üst düzey devlet adamları ve memurların fiziksel görünüşlerine ve kıyafetlerine yönelik de ayrıntılı bilgiler vermişlerdir. Örneğin C. Fellows, memurların rütbeleri arttıkça kıyafetlerinin fiyatı ve görünümünün değiştiğine dikkat çekmiştir. Gezgin askeri üniformaların Türklerin bütün kıyafetlerini ve şişman vücutlarını örttüğünü ve bele takılan kemerin kıyafeti sarıp sarmaladığını bildirmektedir. C. Fellows, Osmanlı yöneticilerin uzun sakallarının at üzerinde gülünç göründügünü, Türkiye'de üst sınıftan kişilerin şimdilerde atın eyerini Avrupa tarzında yaptıklarını belirtmiştir. Fakat bazılarının süslü deriden hoşlandıklarını, bunu mor veya koyu kırmızı renkli kadife, altın veya gümüş ile süslediklerini, deri tabancalıkları da şekillerle bezediklerini bildirmektedir. Fellows'a göre atlar genellikle küçük fakat çok güzel ve gösterişlidir. Gezgin at üzerindeki her önemli kişinin arkasında mevkiine göre bir, iki, üç veya dört tane hizmetlinin yürüdüğünü ve efendisinin tütün çubuğunu taşıdığını bildirmektedir (Fellows, 1852, ss. 68, 243-244).

Gezgin Davis ve arkadaşları, Adana Valisi Safvet Paşa'yı ziyaret ettiklerinde onun heybetli, uzun boylu, iriyarı, yaşlı ancak bakımlı olduğunu, hal ve tavırlarının itidalli olduğunu bildirmektedir. Davis, Safvet Paşa'nın son derece gösterişli gümüş bir nargile içtiğini, nargilenin hortumunun da 7 veya 8 feet $(2-2.5 \mathrm{~m})$ uzunluğunda olduğunu bildirmiştir. Gezgin, paşanın makamına girince kendilerine de nazik bir şekilde kahve ve sigara ikram ettiğini ayrıca seyahatleri süresince her türlü yardımı yapacağını bildirdiğini ifade etmiştir. Davis, Safvet Paşa'nın Fransızcayı gayet akıcı bir şekilde konuşabildiğini ve eski zamanlardaki "zalim davranışlarından" daha farklı bir tutum sergilediğini de belirtmiştir (Davis, 1879, ss. 51-52).

Gezgin C. Fellows, İzmir Valisi'ni ziyaret ettiğini, valinin çok fazla tütün içtiğini, tütün içilen çubuğun çok değerli olduğunu, ağızlık bölgesinde limon rengi amber olduğunu ve çevresinin elmas ile işlendiğini bildirmektedir. Fellows, valinin şarap içmeyi peygamberin 
yasaklamasından dolayı reddettiğini ancak rom ve brendi gibi içkileri peygamberin kelimesi kelimesine yasaklamamasından dolayı sorun olmadan içtiğini bildirmektedir (Fellows, 1852, s. 5, 77).

Gezgin Spry, Türk yöneticilerinin fiziksel görünümlerinden bahsederken arkadaşı Jolliffe ile ramazan ayında Boğaziçi'nde oturan sadrazamın konağına ziyarete gittiğini bildirmekte ve sadrazamın ufak tefek, zayıf, ince, bisküvi yüzlü bir kişi olduğunu ve Türk memurlarıyla karşılaştığında genellikle belirsiz bir yüz ifadesi takındığını, yüzünün kuru ve solgun olduğunu, mavi gözlerinin donuk, çukurlaşmış ve yarı kapalı bulunduğunu ifade etmektedir (Spry, 1895, s. 91).

Spry, sarayda gördüğü yöneticilerin kıyafetleri hakkında da bilgiler vermektedir. Ona göre buradaki görevlilerin kıyafetleri göz kamaştırıcı bir muhteşemliğe sahiptir. Sultanın korumalarının başlarında gümüşler bulunmakta olup, bunların uzun gömlekleri ve kuşakları altın mücevherler ile süslüdür. Sadrazamın hizmetindeki askerler ise ellerinde sembolik nişanlar ve mızrakları ile dolaşmaktadır. Gezginin bildirdiğine göre yüksek rütbeli devlet adamları da rütbelerini belli eden özel renkli kıyafetler giymektedir. Mesela sadrazam solgun yeşil renkli kıyafetiyle, büyük ulema menekşe rengi kıyafetiyle, müftü beyaz kıyafetiyle ve şeyhler açık mavi renkli kıyafetleri ile birbirinden ayrılmaktadır. İmparatorluk ordusunun komutanı, koyu yeşil renk giyer ki herkesin kutsal kabul ettiği rengi taşır. Ordudaki generaller kırmızı çizme giyer, saraydaki sivil memurlar sarı ve din adamları mavi giyerler.

Gezgin Spry'ın ilgisini çeken diğer bir şey ise II. Mehmed'den (1451) II. Mahmud'a (1808) kadar olan yirmi beş Osmanlı padişahının orijinal tören kıyafetlerinin sergilendiği büstler olmuştur. Gezgine göre padişahlar son derece muhteşem görünmekte, üzerlerinde güzel süslerle süslenmiş ipek kıyafetler, altınla süslenmiş kaşmir kumaşlar, Bursa kumaşı ve ipeklerle süslü dökümlü pantolonlar, değerli taşlarla kaplanmış kuşaklar, paha biçilmez altın kılıç kınları ile kabzası elmaslarla kaplanmış palalar bulunmakta, tüfekler ve kamalarda ince işçilikle süsler kullanılmıştır. Geleneksel terlikler keçi derisinin işlenmesiyle yapılmıştır. Başlıklarda ise olağanüstü işçilik ve düzen görünmemekte, sarıklar zengin mücevherlerle süslenmiş durumdadır (Spry, 1895, s. 7, 14-15).

\subsection{Yöneticilerin Nazik ve Cömert Tutumları}

Gezginlerin Osmanlı yöneticilerinde vurguladıkları özelliklerden birisi nazik olmalarıdır. $\mathrm{Bu}$ anlamda bir Türk yöneticisini gördügü için kendisini şanslı sayan W. Wittman, Sadrazam Kör Yusuf Ziyaeddin Paşa'yi ziyaret ettiğini, paşanın Türk tarzı çok zengin döşeli bir odanın köşesinde oturduğunu ve etrafinda olağanüstü güzel ve zarif giyinmiş hizmetkârlar tarafından çevrelendiğini ifade etmektedir (Wittman, 1803, s. 7-8, 45-46).

Gezginler Osmanlı yöneticilerinin cömert ve ulaşılabilir olduklarını dile getirmişlerdir. XIX. yüzyılın son yıllarında Osmanlı ülkesine gelen Spry, ramazan ayındaki adetleri anlatırken bu ay boyunca insanların sadece çevredeki eşine dostuna değil dilenci ve yolculara da yiyecek verdiklerini ifade etmiştir. Eski zamanlarda pek çok ailenin yaptığı gibi şimdilerde de insanların evlerinin kapılarının hayır için açıldığını, bu tür uygulamaların halen sadrazamın konağında devam ettiğini bildirmektedir. Gezginin ifadelerine göre sadrazamın konağında güneş battıktan sonra kapılar asla kapanmaz ve her kim olursa içeri girmesi için ricada bulunulurdu. Gelenlere serinletici şeyler ikram edildikten sonra asla eli boş gönderilmez, yılın bu çok kutsal ayında Doğululara has misafirperverlikle, iyilikle ve yardım severlikle fazlasıyla yardımlarda bulunulurdu. Gezgin bu sırada halkın şikâyet ve dileklerinin de dinlendiğini bildirmektedir.

Spry da sadrazamın huzuruna çıkmıştır. Selamlığın üst katına çıkan gezgin burada seçkin bir kalabalığın toplandığını, ev sahibi olan sadrazamın haremde olduğu ve henüz hazır olmadığ için misafirlerin yanına çıkmadığını bildirmektedir. Bir müddet sonra misafirlerinin yanına çıkan sadrazam uzun ve büyük salondakileri saygılı bir şekilde selamlamıştır. Akabinde gezgin, 
sadrazamın yanına hürmetkâr bir tavırla yaklaştıklarını sadrazamın da kendisi ve arkadaşına dostça hoş geldin dediğini bildirmektedir (Spry, 1895, s. 88, 91).

1898 y1lında İzmir'de bulunan Alman diplomat ve gezgin Rudolf Von Lindau, şehirde bulunduğu sırada İzmir paşasını ziyaret ettiğini, paşanın kendilerini kapıda görünce diğer Türklerin de özelliği olan kibarlıkla selamladığını, oturması için yer gösterdiğini ardından da hoş bir sohbete başladıklarını anlatmaktadır. Gezgin yaklaşık on beş dakika yanında kaldığında konuşmalarının sık sık içeri giren memurlar tarafından bölündüğünü fakat paşanın buna rağmen sohbeti bölmek istemediğini ve konuşmasına devam ettiğini bildirmektedir. Gezgin, paşanın kendisini dinlemeye özen gösterdiğini, bir yandan da sürekli olarak elinde tuttuğu altın tabakayı karıştırıp durduğunu bildirmektedir. Gezgin bu seçkin insanın her davranışının ve her sözünün kendisinde saygı uyandırdığını, bakışlarının ciddi ve davranışlarının yumuşak olduğunu ifade etmektedir (P1nar, 1994, s. 152).

\subsection{Yöneticilerin İhmalkârlık ve Tembellikleri}

XIX. yüzyılda kaleme alınan seyahatnamelerde yöneticilerin tutumlarından kaynaklanan zaaflar sıklıkla dile getirilmiş̧ir. Bu özelliklerden birisi de yöneticilerin vurdumduymaz ve tembel tavırlarıdır. Bazı gezginlerin seyahatnamelerinde Osmanlı yöneticileri "ihmalkâr, tembel ve beceriksiz" olarak nitelendirilmiştir. Örneğin XIX. yüzyılın ortalarında Erzurum'dan Kars'a seyahat eden W. R. Holmes, yol boyunca karşılaştığı uygulamalara dayanarak Türkiye ve Türk idarecilerin zihniyetleri hakkında bilgiler vermektedir. W. R. Holmes gezdiği dönemde kendisine anlatılanlardan hareket ederek yöneticilerin tutumlarıyla ilgili şu bilgiyi aktarmıştır; 1846 yılında Kars valisi olan Bahri Paşa, Erzurum ile Kars arasında kervanların daha rahat seyahat etmesini sağlamak üzere bir han yaptırmıştır. Ancak han henüz kullanılmaya başlanmadan paşa başka bir yere tayin edilince halk, yapılan bu hanı yıkıp kerestesini yakacak olarak kullanmıştır. Bu duruma yeni gelen paşanın hiçbir müdahalede bulunmaması gezgin tarafından eleştirilmiş̧tir (Ersoy, 1964, s. 239-240).

F. Burnaby de Osmanlı yöneticilerini ve halk1, tembel olmaları nedeniyle sert bir eleştiriye tabi tutmaktadır. O, Divriği' de maden ocaklarının çok zengin olduğundan bahsederken Anadolu insanının bu hazinelere nasıl ulaşacaklarını bilmediklerini, bilseler bile bunları işletmek için harekete geçemeyecek kadar tembel olduklarını çünkü "kafalarının bomboş" olduğunu ifade etmiştir. Burnaby, Sapanca'yı geçtikten sonra demiryolu inşaatı için hazırlıkların başlatıldığı bir alanda, yarısı tamamlanmış bir toprak setin kenarında kıvrılarak uyuyan insanları gördügünü ve demiryolu için iki yıldır hiçbir çalışma yapılmadığını, bu demiryolunun Ankara'ya kadar döşenmesinin planlandığını bildirerek bu konu ile ilgili yönettiği her soruya "para yok" yanıtını aldığını bildirmektedir. Ayrıca Geyve köyüne gelmeden önce geçtiği bir köprünün orta kısmının çöktüğünü, açılan bu boşluğun baştan savma bir şekilde, gevşek toprak ve tahta kirişlerle kapatıldığını ancak gerektiği gibi onarılmadığını belirtmekte, Osmanlı yöneticilerinin ihmalkâr tavırlarını eleştirmektedir (Burnaby, 2000, ss. 81-82, 207, 243). Burnaby, Türklerin üzerlerinde var olan vurdumduymazlıktan ve tembellikten kurtulmadıkları sürece diğer milletler karşısında ayakta kalamayacaklarını vurgulamaktadır (Burnaby, 2000, s. 285).

XIX. yüzyılın son döneminde Osmanlı ülkesine gelen E. J. Davis de Türk yöneticileri ve yönetim sistemi hakkında pek olumlu görüşler bildirmez. Gezgin Davis, yüzyılın sonlarında Mersin ve çevresinde karşılaştığı fakirliğin sebebini Türk yöneticilerinin ihmalkâr tavırlarına bağlamaktadır. Davis'e göre Mavromati isimli bir Rum tüccar, Adana ve Tarsus ovalarının sulanması için kanallar vasıtasıyla Seyhan ve Tarsus nehirlerinden su getirilebileceğini ifade ederek bunun karşılığında yirmi yıllık vergiden muaf tutulmasını talep etmiş, ancak Osmanlı yöneticileri bunu kabule yanaşmamışlardır (Davis, 1879, s. 17-18). Gezgin aynı konuda bir başka örnek daha vermektedir. Kıtlık zamanlarında Ermeni tüccarlardan birisi Kıbrıs ve Ermenistan’da incelemeler yaparak Türkiye'ye buğday ithal etmiş, ancak şehrin valisi zimmetine para geçirmiş ve kendi hesabına satış yapmıştır. Tüccar "nankör Türklerle" konuştuğunda onların gözlerinde 
kendilerinin sadece "gavur" olduğunu ve meseleyi anlamadıklarını bildirmektedir (Davis, 1879, s. 17-18).

Görüldüğü gibi E. J. Davis, Türkiye'deki olumsuzlukların ve fakirliğin sebebini yöneticilerin beceriksizliğine ve yönetim sistemine bağlar. Davis gezdiği yerlerdeki yabanc1 görevlilerden aldığı bilgileri aktarmayı ihmal etmemiş, bu örnekler üzerinden Türk yöneticileri değerlendirme çabası içerisine girmiştir. Örneğin Davis, Adana'da bulunan Alman asıllı maden mühendisi Mr. Fishbach ile görüştüğünü, bu kişinin Kilik Nehri çevresinde antik dönemden kalmış bir altın madeni keşfettiğini, bir miktar altın madeni yanında zengin bir gümüş damarının da tespit edildiğini fakat Türk yönetiminin ihmalkârlık sebebiyle madeni işletmediğini kendisine aktarmıştır. Aynı şekilde Yumurtalık Ayas'ta yaklaşık elli metre derinlikte bulunan zengin kömür madeninin varlığını dönemin Adana Valisi Mahmud Paşa'ya bildiren Fishbach, bu teșebbüsten de bir netice alınamadığını Davis'e bildirmiştir (Davis, 1879, ss. 53-54; Şahin, 2016, s. 66). Anlaşılacağı üzere gezgin, yöneticilerin tembelliği ve beceriksizliği yüzünden kaynaklarının verimli bir şekilde kullanılamadığını ifade ederek kaynakları daha verimli işletecek güçlü bir hükümete ihtiyaç duyulduğunu vurgulamaktadır.

Gezgin C. Fellows, Türk yöneticileri ile ilgili izlenimlerini anlatırken görevlilerin keyiflerine düşkün ve iş disiplininden uzak olduklarını dile getirmiştir. Bununla ilgili yaşadığı bir olayı nakleden Fellows at alabilmek için resmi evrakını imzalatmak amacıyla posta merkezine gittiğini ancak görevlinin hamamda olduğu için saat sekize kadar kendileri ile ilgilenmediğini bu nedenle saatlerce memurun keyfini beklemek zorunda kaldıklarını dile getirmiştir. Fellows, yöneticilerin sabah saat 11.00 'den önce işlerinin başında olmadıklarını, günlerin büyük bölümünü haremlerinde, banyoda ve camide geçirdiklerini bildirmektedir. (Fellows, 1852, ss. 5, 77). İngiliz elçisi Canning de işlerin yavaş işlemesinden yakınmıştır. Bir iş için Bâbıâli'ye gittiğinde kendisine "adet olduğu üzere" çubuk ikram edildiğini bunun üzerine kendisinin önce halledilmesi gereken işin bitirilmesini talep ettiğini kaydetmektedir (Poole, 1999, ss. 84-85).

\subsection{Despotizm ve Kurnazlık}

Türkiye'yi ziyaret eden gezginlerden bir kısmı Türk yöneticilerini despotlukla suçlamışlardır. Örneğin Tott, Türk yöneticisini "despot ve her gün yeni vahşet manzaraları sunan baskıcı rejim sebebiyle otoritesini herkese kabul ettiren" kişiler olarak tasvir etmektedir (Tott, ty, ss. 26, 67). 1838 yılında Osmanlı ülkesine gelen Charles Fellows, İzmir Valisi'ni ziyareti sırasında şehirdeki vali ve kadı gibi yöneticilerin çok güç sahibi ve despot kişiler olduklarını bildirmektedir. Gezgine göre bu idarecilerden birisi dilediğince yargilamakta, diğeri ise dilediğince cezalandırmaktadır. Vali, belli bir para karşıllı̆ında sultandan toprak kiralamakta ve vergi, harç ve para cezalarını istediği gibi vermektedir. Böylece kısa sürede önemli gelirler elde etme imkanına sahip olmuştur. Gezgin, halkın yaşaması veya ölmesinin yöneticilerin ellerinde olduğunu dile getirmiştir (Fellows, 1852, s. 5).

Fellows'un bu izlenimlerinin tam tersi olarak XIX. yüzyılın ortalarında Türkiye'yi ziyaret eden gezgin Burnaby, İstanbul'da aşırı özgürlükten bahsetmiştir. Burnaby arkadaşlarının ifadelerini referans göstererek "İstanbul'da bir şey varsa o da aşırı özgürlüktür" ifadelerini kullanmıştır. Gezgin, gazetelerin dilediklerini yazabildiğini, hükümeti gönüllerince yerden yere vurabildiğini, bütün bunları yaparken gazetelerin hiçbir baskı görmediğini ifade etmiştir. Hatta Türkiye karşıtı yayın yapan bazı İngilizce gazetelerin dahi bütün kitapçılarda satılmakta olduğunu bildirmiştir (Burnaby, 2000, s. 45). Bu yüzyılda Türkiye karşıtı yayın yapan yabancı gazetelerin İstanbul'da satılıyor olması ve gezginin ülkenin özgür olduğunu söylemesi despotizmden uzak bir yapının varlığını ortaya koymaktadır.

Dorina L. Neave, Türk yönetim yapısı ve yöneticileri ile ilgili bilgiler verirken Osmanlı Padişahı II. Abdülhamid'in Avrupa'nın "en hayrete şayan ve en çok korkulan şahsı" olduğu fikrindedir. Neave'ye göre padişah, amacına ulaşmak için "düşmanlarını zehirleyen, denize attıran, süren, mallarını alan ve aynı zamanda son derece kurnaz" bir diplomattır. Padişah kendi 
vekillerini ve Avrupa devletlerinin elçilerini parmağında oynatabilmektedir. Padişahın etrafında bulunan "ahlaksız memurlar ve casuslar" halka hayatı zehir ederdi. Yabancılarla konuşan, konsolosluklara giren Türklerin hayatı tehlikeye girebilirdi.

Neave'ye göre padişah her sabah casuslarının jurnallerini okurdu. Tabii padişahın her an korku içinde olduğu muhakkaktı. Öldürülmekten korkan Sultan II. Abdülhamid'in muhafız kıtasından başka uyurken dahi başucunda bekleyen adamları vardı. Yastı̆̆ının altında tabanca bulunurdu. Ancak Sultan II. Abdülhamid tehlike karşısında soğukkanlılığını muhafaza edebilirdi. Mesela cuma selamlığı töreni sırasında padişaha bomba atılmış fakat bombanın vaktinden önce patlaması yüzünden padişah kurtulmuş, aynı gün sanki hiçbir şey olmamış gibi dört elçiyi kabul etmiştir. Nitekim bir defa İngiliz Sefirini kabul ederken, sefirin cebinden mendil çıkarmak üzere elini cebine atmasından şüphelenmiş ve sefir başını kaldırdığı zaman padişahın elindeki tabancayla karşı karşıya kalmıştır (Neave, 1978, s. 26-27; Uzmen, 1969b, s. 51-52). D. Neave'nin bildirdiğine göre, II. Abdülhamid, halka görünmekten çekindiği için herhangi bir tören sırasında geçeceği yolları gizli tutmuştur. Örneğin Topkapı Sarayı'na gideceği zaman Galata Köprüsü üzerinde kimsenin durmasına izin verilmezken padişah Haliç'i motorla geçip saraya ulaşmıştır (Neave, 1978, s. 30-33).

D. Neave, dönemin etkili isimlerinden Fehim Paşa hakkında oldukça olumsuz izlenimler aktarmaktadır. O, zalim Fehim Paşa'nın ve idaresi altındaki zaptiye teşkilatının halka ve her güzel kadına hayatı zehir etmekte olduğunu, zira bu ahlaksız adamın erişebildiği herkesi mahvetmek istediğini, zeki, aynı derecede kötülük dolu, divanın bu en etkili nazırından herkesin korktuğunu bildirmektedir. Gezgin, masumları gözden düşürmek için garip bir uygulaması olan bu adamın, zamanını başkalarının hayatları ve hürriyetleri pahasına zenginliğini artırmak için, şeytani düzenler kurarak geçirdiğini, sultanın kendisinden başka ülkede daha çok korkulan bir adamı olmadığını belirtmektedir. Fehim Paşa'nın meşhur, parlak sarı arabasının yaklaştığını görünce panik içinde halka karışıp, paşanın gözünden ırak olmanın yapılacak en akıllıca iş olduğunu ifade eden Neave, arabasıyla gezintiye çıkan Türk hanımlarının Fehim Paşa'yı gördüklerinde "arkalarından koşan bu canavardan saklanmak için, aceleyle peçelerini örtüp arabanın perdelerini indirirlerdi" ifadesini kullanmıştır.

Neave, Fehim Paşa ile ilgili anlattıklarını doğrulayacak şekilde bizzat kendi şahit olduğu şu örneği vermektedir. Bir gün Beyoğlu'ndaki İngiliz mağazası Hayden'de alışveriş ederken, kumaşlara bakan Türk arkadaşlarına rastlayan Neave, onların arabalarını dükkanın önünde gören Fehim Paşa'nın da içeri girdiğini, onun varlığını fark eden kızların birden kumaş seçmekten vazgeçerek peçeleriyle yüzlerini örttüklerini ve tek kelime söylemeden dükkandan dışarı fırladığını bildirmektedir. Onlara hizmet eden mağaza sahibi, güzel müşterilerinin bu ani kayboluşlarının sebebini keşfedinceye kadar şaşkınlıktan kurtulamamıştır. Fehim Paşa'yı çok merak eden gezgin, paşayı tarif ederken; "yağll, esmer yüzünü, iğrenç yüz hatlarını, zalim ve kurnaz baklşlı gözlerini görünce, korkulan ve nefret edilen biri olmasına şaşmadım" (Neave, 1978, ss. 65-66) demiştir.

\subsection{Rüşvet ve Hediye Düş̧ünlüğü}

Gezginler, Osmanlı Devleti'nde gelenekselleşen hediyeleşme kültürünü çoğu zaman rüşvet olarak algılamışlardır. Osmanlı Devlet teşkilatında karşılaşılan ve "câize, pişkeş, avâid, dest-âvîz, bohça" vb olarak anılan hediyeleşme, devlet kademelerinde kurumsal bir uygulamadır. Gezginler bu tür teşrifata rastladıklarında kurumsal bir meseleyi genelleştirerek tamamen rüşvet olarak değerlendirmişlerdir. Gezginler tarafından hediye kategorisinde olan aynî veya nakdî eşyanın tamamının rüşvet kapsamında değerlendirilmesi, ülkedeki teşkilat yapısını bilmemekten kaynaklanmaktadır. Bu tür hatalara düşülmesinde, kanunnameler ve nizamnamelerde 1840 yılına kadar rüşvetin tanımının tam olarak yapılmamış olmasının yanında, rüşvet kapsamına giren veyahut girmeyen hediyelerin cins ve miktarının 1850 yılına kadar belirlenmemiş olması önemli rol oynamıştır. (Çelik, 2006, ss. 26-27; Uzun, 1993, s. 29). 
Gezginlere göre Osmanlı yöneticilerinin en belirgin olumsuz özellikleri "rüşvete ve hediyeye olan yatkınlıkları, keyfi uygulamaları ve despotluklarıdı". Pek çok gezgin bu özelliklerden bahsetmektedir. Yöneticilerin hediye merak1 ile ilgili özellikleri XVI. yüzyılda Osmanlı topraklarına gelen İngiliz tüccarlar tarafindan da vurgulanmaktadır. $\mathrm{Bu}$ dönemde Venedikliler tarafından Osmanlı padişahına verilen hediyeler arasında iki kişinin taşıyabileceği altın yaldızlı gümüşten model gemi, kumaşlar, tabak çeşitleri, dört sepet parma peyniri, bir miktar beyaz mum ile kelle şeker çuvalları bulunmaktadır (Mayes, 2000, ss. 76-77).

XVII. yüzy1lda sadrazam ve vezirlerden söz eden P. Rycaut, rüşvetin son derece yaygın bir alışkanlık olduğunu, gizli değil açıktan rüşvet pazarlıklarının yüksek rütbeli görevlilerce yapıldığını anlatmaktadır. Ona göre rüşvet alanların başında veziriazam ve vezirler gelir. $\mathrm{Bu}$ hastalık toplumun tüm katmanlarına yayılmıştır. Bunlardan bazılarının servetleri padişahın servetini kat kat geçmiştir (Erhan, 1996, ss. 52-53; Tott, ty, s. 283). XVI. yüzyılın sonlarına doğru Türkiye'ye gelen Baron Vratislav, Türkiye'de rüşvetin çok yaygın olduğunu, özellikle yabancıların keselerinin ağızlarını açık tutmak zorunda olduklarını ve tohum saçar gibi para saçmak zorunda kaldıklarını dile getirmiștir (Vratislav, 1988, s. 41; Mayes, 2000, s. 150). Benzer şekilde 1698-1700 yıllarında İzmir'de bulunan Edmund D. Chishull, Manisa gezisi sırasında tercümanlarının kentin kadısını ziyaret etmenin münasip olacağını ve oraya boş elle gidilmemesi gerektiğini bildirmesi üzerine, kadıyı makamında iki kelle şeker ve bir miktar kahveyle ziyaret ettiklerini, kadı efendinin ise kendilerini ve armağanları nazikane kabul ettiğini bildirmektedir (Chishull, 1993, s. 29).

Gezginler rüşvetle ilgili eleştirilerini sıklıkla dile getirmişlerdir. Örneğin 1835 'te Türkiye'ye gelen Miss J. Pardoe, İstanbul'dan Bursa'ya seyahatini anlatırken gümrük memurlarının tutumundan şikayet etmiştir. Gezgin, Türkiye'de bir turistin ilk öğrendiği sözcüğün bahşiş olduğunu, gümrük görevlisinin kendilerinden de bahşiş istediğini dile getirmiştir. Pardoe'ye göre Türkiye'de bahşişsiz hiçbir şey yaptırılamazdı (Pardoe, 1997, s. 115). Benzer șekilde 1845 yılında İzmir'e gelen Ludwig Ross da gümrük memurlarından şikayet etmiștir. Ross'un bildirdiğine göre gümrük memuru ilk valizini açmış, diğer valizini açtırmak istemiyorsa beş kuruş vermesi gerektiğini söylemiştir. Kendisinin memura iki kuruş önerdiğini bildiren Ross, eğer bu miktarı beğenmezse diğer valizini de kontrol edebileceğini ifade etmiştir. Bunun üzerine gümrük memuru iki kuruşa razı olmuştur. Gezgin Türkiye'de her şeyi satın almanın mümkün olduğunu, paşanın makamını nazırdan satın aldığını, en alt düzeydeki memurun da görevini satın aldığını ve devrederken de para talep ettiklerini ifade etmektedir. Bu anlamda 1860 yılında Anadolu'ya gelen Herman Scherer, Türkiye'de rüşvetin ve bahşişin çok yaygın olduğunu ancak kendisinin İzmir'de bulunduğu sırada gümrükte bahşiş vermeyi ilke olarak reddettiği için gümrük merkezine başvurduğunu anlatmaktadır (Pınar, 1994, ss. 86, 107).

Benzer ifadelere F. Burnaby'nin eserinde rastlamak mümkündür. Gezgin, "bavulların incelenmesini istemeyenlerin gümrük müfettişinin avucuna bir miktar para sıkıştırarak meseleyi hallettiğini" bildirmektedir (Burnaby, 2000, s. 44). Yine 1862 y1lında İstanbul'a gelen ve Türk memur ve yöneticilerinin özelliklerini aktaran Perulu gezgin Pedro Paz Soldan'ın izlenimleri de aynı doğrultudadır. P. Soldan, karaya çıktıklarında gümrük memurlarının eşyalarını incelemesini anlatırken her şeyini karıştırdıklarını, ancak Çin malı açılmamış mendiller ile Süveyş, Kahire ve Şam ziyaretlerinde satın aldığı çeşitli eşyaya hiç dokunmadıklarını bildirmektedir. Gezgin gümrük memurlarının saygısız davranışları nedeniyle bahşiş vermediğini ancak bu davranışının kendisine pahalıya patladığını, bu memurların yan taraftaki memur arkadaşlarına haber vererek hakları olmadığı halde eşyalarının başına “akbabalar gibi üşüştüğünü’ ve Şam'dan aldığı üç adet tütün içilen uzun çubuğa el koyduklarını anlatmaktadır. Soldan, çubukları 1srarla istemiş ancak başarılı olamayınca şeflerine iki frank rüşvet ödemesi sonucunda çubuklarını geri alabildiğini ifade etmiştir (Önalp, 2000, ss. 877-878).

Gezgin Davis de rüşvetten bahsetmiştir. Davis'in bildirdiğine göre Halil Paşa'dan sonra Mersin, Tarsus ve Adana arasına inşa edilmesi planlanan yol ihmal edilmiştir. Gezgine göre 1869- 
1871 yılları arasında yönetici olan Takieddin Paşa “rüşvetçi, tutucu, cahil ve çok kötü” bir kişidir. Onun ardından göreve gelen Nasib Paşa da benzer şekilde rüşvetçi olup ve bu nedenle yollar tamamlanamamıştır. Yapımı planlanan yol ancak 1873 yılında Sadrazam Mahmud Paşa zamanında tamamlanabilmiştir (Davis, 1879, ss. 28, 55-56; Şahin, 2016, s. 66). Davis, Ulukışla'nın içinde bulunduğu sorunlardan bahsederken vali dahil herkesin rüşvete bulaştığını ve halkın ekonomik olarak sıkıntıya düştüğünü bildirmektedir (Davis, 1879, s. 230; farklı dönemlere ait örnekler için Kurnaz Şahin, 2019, s. 418). Davis'in ifadelerinden anlaşılacağı üzere yönetimde görülen olumlu gelişmeler ancak bireysel çabalarla gerçekleşmektedir. Şayet yöneticiler liyakatli ve becerikli iseler kanunları tam olarak uygulamış ve ahalinin sorunlarına eğilmişlerdir. Ancak yöneticiler yeteneksiz ise yönetim yapısı da problemlere sebep olmuştur.

Yöneticilerle ilgili benzer bilgilere İngiliz konsolos W. R. Holmes’ta da rastlanmaktadır. Holmes, yöneticilerin konuşurken makul kişiler olarak göründüklerini, hatta yüksek hisleriyle ögündüklerini ancak iş uygulamaya geldiğinde "maddiyatçı ve bencil" olduklarını ifade etmektedir (Ersoy, 1964, s. 249). Benzer şekilde Moltke de diğer bütün Doğu toplumlarında olduğu gibi Osmanlı ülkesinde de hediyenin adet olduğunu bildirip ahaliden birisinin yukarıya hediyesiz yaklaşamadığını kaydetmektedir (Moltke, 1969, s. 46). Moltke'nin yaptığ1 adet vurgusu, aslında yukarıda da bahsedildiği üzere Osmanlı yönetim sisteminin bir yansımasıdır. Gezginler Osmanlı teşkilat yapısına yabancı olduklarından, gerçekte kanun, nizam ve teamüllerden kaynaklanan bazı hususları bilmediklerinden her şeyi rüşvet gibi değerlendirmişlerdir (Çelik, 2006, ss. 31-32). Keza Osmanlı hükümeti, 1840 yılından itibaren rüşvetle ilgili gerekli yasal düzenlemeleri yaparak Tanzimat'ın getirdiği esaslara aykırı olarak hareket eden, rüşvet alan dönemin tanınmış kişileri de olsa cezalandırma yoluna gitmiştir (Keleş, 2005, s. 268).

\subsection{Yöneticilerin Halkla İlişsilerine Dair Gözlemler}

XIX. yüzyılda Osmanlı Devleti’nin içinde bulunduğu finansal krizler halkın hükümete ve yöneticilere karşı hoşnutsuzluğunu artırmıştır. Özellikle yüzyılın ikinci yarısında bu hoşnutsuzluk ekonomik sefaletle birleşmiştir. Ekonomik yapı gittikçe bozulmakta, yüzyılın ortalarında ordu mensupları dahil hükümet memurlarının maaşlarının ödenmesinde bazen haftalar bazen aylar bulan gecikmeler yaşanmaktadır. Beyoğlu'ndaki tüccarlardan ağır şartlar altında borç alınmakta, hazinenin içinde bulunduğu buhran gittikçe daha da kötüleşmektedir. Hatta tasarruf yapılması için fermanlar dahi yayınlanmaktadır (Cevdet Paşa, 1991a, s. 21, Cevdet Paşa, 1991b, ss. 85, 86, 226; Davison, 1997, ss. 90-91). Bu memnuniyetsizlik yabancı seyyahların gözünden kaçmamış, kaleme aldıkları eserlerde halk ve yöneticiler arasındaki gerginlikler, çatışmalar ve bunların kaynağı üzerinde izlenimler dile getirilmiştir.

XVIII. yüzyılda gezginlerin dikkatini çeken ve hükümdarların karşılaştığı önemli sorunların başında İstanbul'a yiyecek ve su tedarik edilmesi gelmektedir. Bu anlamda B. De Tott, İstanbul ve civarının "çı̆̆ırından çıkmış askerler" tarafından istila edildiğini, bu başıbozukluk içinde ve yöneticilerin ağır vergileri altında halkın inlediğini, vezirlerin tek amacının ise İstanbul'un yiyeceğini temin etmek ve askerin maaşının ödenmesi olduğunu ifade etmektedir. Bu durum halkın hem vergiler hem de vergi memurlarının baskısı altında ezilmesine sebep olmaktadır (Tott, ty, ss. 20-21, 247). XVIII. yüzyllda Türkiye'ye seyahat eden gezgin Giambattista Casti, Türklerin hayırseverliklerinden bahsederken Osmanlı hükümetinin "yapmak zahmetine katlanmadiğ l yollar, han ve kervansarayların hayırseverler tarafindan" inşa edildiğini bildirip yönetim anlayışını eleştirmektedir (Öncel, 1969, s. 83). Gezgin Raczynski'ye göre ise şehrin su ihtiyacının karşılanmaması isyanlara neden olduğundan bu konunun halledilmesi için hiçbir masraf ve çalışmadan kaçınılmamaktadır. Padişahlar su tesislerini muhafaza etmek için devamlı kontrol altında bulundurmuşlardır (Raczynski, 1980, s. 67).

Bütün gezginler aynı düşüncede olmayıp kimi gezginler, yöneticiler ile halk arasındaki münasebetleri beğeni ile anlatırlar. Örneğin Levent Çiftliği'nde Osmanlı Sultanı III. Selim ile karşılaşan W. Wittman, onun halk tarafından çok sevildiğini, sultanın bir hükümdarın sahip 
olması gereken yetenek ve ehliyete sahip olduğunu bildirmektedir. Keza Sultan III. Selim'in Türkiye'de daha önceki nesillere uygulanan ve başarılı olmayan eğitimden daha liberal bir eğitim gördüğünü kaydetmektedir. Wittman devamla Sultan Selim'in kültürlü, akıllı ve geniş görüşlü olduğunu, Avrupa'nın politikalarını takip ettiğini, bundan dolayı Osmanlı Devleti'ne birçok yenilik getirmesinin şaşırtıcı olmadığını ifade etmektedir (Wittman, 1803, s. 45).

İngiliz gezgin Burnaby halkın kamu hizmetlerinde çalıştırılması sırasında yöneticilerle halk arasında bazı sorunlar yaşandığını bildirmiştir. Malum olduğu üzere Osmanlı Devleti’nde kamu hizmetlerini gerçekleştirmek için halka müracaat edilmekteydi. Gezgin, Tokat şehrinde bulunduğu sırada burasının nüfusunun toplam 25 bin olduğunu, bu nüfusun 8 bininin yılda dört gün yol yapımında çalışması gereken erkeklerden oluştuğunu ifade etmektedir. Böyle zamanlarda zaptiyelerin halkı topladığını anlatan Burnaby, zenginlerin rüşvetle işlerini hallettiklerini fakat fakirlerin bu yükümlülükten kurtulamadığını bildirmektedir. (Burnaby, 2000, s. 161).

Gezgin E. J. Davis, vergi toplamanın yönetici ve halk arasındaki ilişkileri sıkıntıya soktuğuna da değinmiştir. Karaman'da halkın son derece zor şartlar altında yaşadığını, yöneticilerin ise halka yardım etmediğini bildirmektedir. Haziran 1876 tarihinde Kilbasan köyüne vergi toplamaya gelen memurlar, köyün zengin dönemlerinde ödenen y1llık 150.000 kuruş vergiyi bu zor dönemde de aynen toplamak istemişler, köylüler ise bu durum karşısında vergiden muaf tutulmadıkları için evlerini ve arazilerini satmak zorunda kalmışlardır. Gezgin, Türklerin sattığı tarla ve arazileri Ermenilerin satın aldığını, "vergi toplayan çakalların, başkasının hesabına alçakça iş gören kimselerin" insanları adım adım takip ettiğini, bu kişilerin kurbanların sadece arazilerine değil diğer mal ve mülklerine de talip olduklarını, bu durumun ise hemen her yerde tekrarlandığını bildirmektedir.

Davis'in ifadelerine göre hükümetin bu “açgözlü istekleri”, halkı neredeyse bütün malını mülkünü satılacak duruma getirmektedir. Öyle ki köylüler, mallarını değerinin beşte biri fiyatına ellerinden çıkarmak zorunda kalmakta, Ermeni ve Rumlar ise bu durumdan mükemmel bir şekilde fayda sağlamaktadır. Benzer durum Ereğli için de geçerlidir. Zaptiyeler halktan vergi toplamak için köye gönderildiklerinde halk hayvanlarını, evindeki eşyaları satmak zorunda kalmaktadır. Gezgin, Karaman'dan köye vergi toplamak amacıyla gönderilen zaptiyeler, köylülerin vergi borçlarını en geç bir gün içinde ödemeleri gerektiği hususundaki uyarılarına, bu sistem altında yaşadıkları için köylülerin şaşırmadığını bildirmektedir. Davis, bölgedeki insanların fakirliğinden, Tarsus'ta bir kadının sadece pamuk bir etek giydiğinden bahsederken yöneticilerin bu durum karşısında hiçbir şey yapmadıklarını, halkı vergi talepleriyle daha da üzdüklerini bildirmektedir (Davis, 1879, ss. 34-35, 237, 303-304).

Gezgin Davis, Adana'yı ziyareti sırasında Safvet Paşa'nın şehrin valisi olarak görev yaptığını bildirdikten sonra onun vergileri tahsil ederken halka zulmettiğine değinmiştir. Davis, Safvet Paşa'nın bu konuda sabıkalı olduğunu, eski görev yeri olan Trabzon'da iken hükümetten çeşitli taleplerde bulunmak üzere bir araya gelen ahalinin uyarılara rağmen dağılmaması üzerine halkın üzerine ateş edilmesi emrini verdiğini bildirmiştir. Söz konusu olay sırasında yaklaşık yirmi kişinin hayatını kaybettiğini de dile getirmiştir (Davis, 1879, ss. 51-52).

Türk yöneticilerinin özelliklerinden ve yönetim sisteminin bozukluğundan bahseden gezgin Davis, Türk köylülerinin yönetimin bozuk olmasını yadırgamadıklarını ve bir gün düzelme ihtimali bulunduğunu düşündüklerini bildirmektedir. Her şeye rağmen özellikle fakir sınıftaki insanların "oldukça iyi, sessiz, uysal ve itaatkâr" olduklarını, dünyada bu kadar "kolay idare edilecek ve az hediye ile büyük avantajlar elde edilecek" başka bir ülkenin bulunmadığını bildirmektedir. Davis, Türklerin rüşvetle ve kötülükle zengin olma ihtimaline karşıllk dinlerinin kendilerini "arkalarından tuttuğunu" da bildirmektedir. Gezgine göre yöneticiler ülkenin iyiliği için kıllarını kıpırdatmamaktadırlar. Türk yöneticiler için üslubunu oldukça sertleştiren gezgin onları "yemlikteki köpekler" diye nitelendirmektedir. Keza o, Türk halkının Osmanlı idaresinden kurtuluşunun, bütün medeni dünyayı şaşkına çevirecek kadar çok miktarda "kan dökülmesine bağgll” olduğunu söylemektedir (Davis, 1879, ss. viii, 17-18). 
XIX. yüzyılın sonlarına doğru Türkiye’ye gelen Amerikalı S. G. W. Benjamin, Türkiye'de zahiri bir ihtişam görüldüğünü ancak vilayetlerde "ezici bir zulüm ile tarife siğmaz bir baskının" bulunduğunu "en altta kalanın canı çıksın" prensibinin halk arasında hâkim olduğunu ifade etmektedir. Ona göre hükümet iflas etmiştir. Rüşvet, kötü idare, açlık, perişanlık ve nüfus azalması imparatorluğun her yerinde almış yürümüştür (Benjamin, 1959, s. 107). Gezginlerin Türk yönetim sisteminin baskı ve zulüm üzerine kurulduğunu anlatırken halkın tembelliğine ve umursamazlığına da atıfta bulunmuştur.

XIX. yüzyılda Türkiye'ye gelen İngiliz arkeolog Sir Ramsay'a göre Türk köylüleri memurlara ve hükümete karşı derin bir itimatsızlık duymaktadır. Köylüler memurlardan korkmakta ve hatta nefret etmektedirler. Köylüler, yabancıların hükümetle ilişkilerinin olduğunu sezdiklerinde onlara yardım etmeye yanaşmamaktadır. Gezgin, Osmanlı yönetiminde Türklerin, Rumlardan daha fazla baskı altında tutulduğunu çünkü Rumların özellikle Batı Anadolu'da birbirlerine destek olduklarını, Türklerin ise her şeye "Tanrının isteğidir" düşüncesiyle şikayetsiz katlandığını dile getirmiştir. Nitekim Ramsay, Kürtlerin baskısı altına terk edilen Ermenilerin bile Batı ve Orta Anadolu'da hükümetin baskısı altında yaşayan Müslüman köylülerin çektikleri sıkıntıyı çekmediklerini ifade etmektedir. Hristiyan köylülerin ekonomik durumları Türklere göre çok daha iyi olduğu gibi memurlara rüşvet vererek kendilerini bir takım zor durumlardan da rahatça siyırabilmektedirler (Uzmen, 1969a, ss. 38-39).

Gezgin Ramsay, Türk zaptiye ve jandarmalarından bahisle bunların tutumlarının daha ziyade bölge amirine bağlı olduğunu söyler. Genel olarak maaş alamayan fakat yine de yaşamak ve ailesini geçindirmek zorunda bulunan zaptiyelerin "her şeye boyun eğen" Türk köylülerini istismar ettiklerini ve bu hareketlerini Kürt, Çerkez veya Avşar köylerinde daha temkinli bir şekilde yürüttüklerini bildirmektedir.

Ramsay’a göre zaptiyenin görevlerinden biri de hükümetin emirlerini köy muhtarına ulaştırmak, vergiler gecikmişse bunun sebebini öğrenmektir. Bu durum geniş ölçüde suiistimale açıktır. Ayrıca rüşvet de yaygındır. Bir suç işlendiği zaman zaptiyeler suçlunun kim olduğunu çoğu zaman bildikleri halde suçsuz kimseleri yakalayıp hapseder ve onlardan epey bir rüşvet koparıp serbest bırakırlardı. Gezgin karşılaştığı zaptiyelerin genellikle kendilerine karşı iyi davrandıklarını, bu kişilerin, hürmetkâr ve becerikli kimseler olduğunu ancak zaptiyelerle görünmelerinin bilhassa köylülerle iş yapmalarına engel olabileceğinden zaptiyelerle gezmemeyi tercih ettiklerini bildirmektedir (Uzmen, 1969a, ss. 39-45).

XIX. yüzyılın ortalarında Türkiye'de bulunan C. Fellows da bu konuda çarpıcı bilgiler vermektedir. Gezgin, İzmir'de birçok aydın kişi ile konuştuğunu, aydınların şehir ahalisinin duyarsızlığından yakındıkları ve bilim ve sanattan anlamamaları nedeniyle üzüntü duyduklarını bildirmektedir. Fakat yine de aydınların umutsuz olmadığını "başımızın üstünde parlak bir güneş ve tam özgürlüğümüz var" dediklerini belirtmiştir. Fellows, her milletin kendine göre özgürlük anlayışı olduğunu, İngilizlerin özgürlük anlayışının çevredeki her şeyi kapsadığını, buna karşılık belirli bir zümreye ait özgürlügün, en kötü zulüm olduğunu dile getirmiştir. Gezgin, Türk kanunlarının insanlara layık gördüğü bu şartları ve şehirlerin açık köle pazarına dönüşmesini özgürlükle bağdaştıramadığını da ifade etmiş̧tir (Fellows, 1852, s. 11).

\section{Sonuç}

Çalışma, XIX. yüzyılda Türkiye'yi ziyaret eden İngiliz gezginlerin, Osmanlı yönetim sistemi ve yöneticilerin özelliklerine dair algılarını ortaya koymak için kaleme alınmıştır. XIX. yüzyılda kaleme alınan İngiliz seyahatnamelerinden elde edilen veriler, Osmanlı'nın algılanışında önceki yüzyıllara nazaran çok köklü bir değişikliğin olmadığını göstermektedir. Zira XVI. ve XVII. yüzyıllarda İngilizlerin zihinlerindeki Türk imajı; zulüm, keyfilik, haraç kesme gibi bazı olumsuzluklar içermektedir. Keza Türklerin dini inanışlarına yönelik tutumlarını eleştiren yazılar da söz konusudur. Ancak farklı olan yaklaşım, XIX. yüzyılda yönetim yapısı ve yöneticilerden bahsedilirken artık zirve noktasında bir imparatorluk imajının çizilmemesidir. $\mathrm{Bu}$ dönem seyahatnamelerinde yönetimin yetersizliği ve devletin içinde bulunduğu çıkmaz gözler önüne 
serilmektedir. Osmanlı Devleti'nin önü alınamayacak bir çöküş sürecine girdiği gezginler tarafından her firsatta vurgulanmaktadır. Keza Osmanlı askeri gücünün ciddi derecede zayıfladığ 1 ve yüzyıllarca devam eden "Türk kudretinin" silindiği de dile getirilmektedir.

İngiliz gezginler, Osmanlı Devleti’nin içinde bulunduğu ekonomik zorlukların yönetim yapısını ve yöneticileri etkilediğini, yönetim yapısının hantallığını, kanunlar ve süregelen dini siyaset nedeniyle zamana uyum sağlanamadığını, bunların sonucu olarak da devletin sorunlarına çare bulunamadığını dile getirmektedir. Ayrıca idarenin tepeden tırnağa kötü olduğuna ve yöneticilerin bunu düzeltmek için cesaretlerinin ve yeteneklerinin bulunmadığına dikkat çekilmektedir. Bu zor işin üstesinden gelmeyi düşünenlerin ise yapılması gereken yenilikleri halkın önyargılarıyla nasıl bağdaştıracaklarını bilemedikleri ifade edilmektedir.

Bir kısım İngiliz gezgin Osmanlı Devleti'ni Roma mirasını yıkan bir yapı olarak karakterize etmektedir. Türklerin göçebe kültürü temsil ettiği önyargısıyla Türklere ait ince bir yönetim anlayışı, keza kültür ve sanat anlayışı yok sayılmaktadır. Türklerin ezeli ve ebedi göçebeliğinden dem vurularak "yüzyıllardır işgal ettikleri Avrupa'da halen yabancı" oldukları iddia edilmektedir. İlaveten ülkelerin kaynaklarını kullandıkları fakat bu ülkelere hiçbir katkıda bulunmadıkları, kent hayatına ve yerleşik yaşama bir türlü ayak uyduramadıkları ifade edilerek Osmanlı’nın kültürel mirası göz ardı edilmektedir. Öte yandan idarecilerin baskıcı yönetimleri, gaddarlıkları ve zulümleri nedeniyle Doğulu halkların kalkınamadıkları, ancak aydın Batılı yönetimler altında muazzam bir refaha kavuşacakları ifade edilmektedir. Anlaşılacağ 1 üzere bu yüzyılda Avrupa toplumunda, Osmanlı yöneticileri hakkında olumsuz bir alg1 oluşmuştur. Böylece Osmanlı Devleti'nin hakim olduğu bölgelerdeki meşruiyeti tartışmaya açılmış, sömürgeci devletlerin müdahalelerine zemin hazırlanmıştır. Diğer taraftan seyyahlar kaleme aldıkları eserlerinde Batı düşüncesini benimsemiş olan Osmanlı yöneticilerden övgüyle bahsetmişlerdir.

XIX. yüzyıl İngiliz seyahatnamelerinde devletin içinde bulunduğu finansal krizlerin yönetimi ve yöneticileri etkilediğine dair kısmen hakkaniyetli değerlendirmeler de yapılmıştır. Yüzyılın sonlarında Türkiye'ye gelen İngiliz arkeolog Sir Ramsay, Sultan II. Mahmud ve ondan önceki padişahların kanunlarının iyi ve hakkaniyet dairesinde hazırlandığını belirtmekte ancak kanunların tam anlamıyla uygulanamadığını dile getirmektedir. Türk memurlarının maaşlarının son derece yetersiz kaldığ1, çoğu zaman ödenemediği ifade edilerek devletin içinde bulunduğu finansal krize dikkat çekilmektedir. Aynı değerlendirmede Türk memurların yetersizlikleri vurgulanmakta, Türklerin karakter itibariyle tembel olduklarından bir memur veya subayın katlanması gereken sıkıntılardan kaçınmayı tercih ettiği eleştirisi yapılmaktadır. Keza yönetimde kuralsızlık ve keyfi uygulamalar nedeniyle "halkın ezildiği, soyulduğu ve gelir kaynăğ olarak görüldüğü’ ifade edilmektedir.

Seyahatnamelerdeki yönetici algısına bakıldığında elde edilen veriler birkaç başlık altında toplanabilir. Gezginlere göre Osmanlı Devleti'ndeki yöneticiler seyyahlara karşı misafirperver ve zarif olmakla birlikte halka karşı acımasız, halkı ezen, bencil ve rüşvetçidir. Gezginler, yöneticileri değerlendirirken merkezi yönetim ve taşradaki yöneticileri de birbirinden ayırmaktadır. Osmanlı ülkesinde merkezi yönetim sistemi, kuralsızlık ve keyfi uygulamalar üzerine kurulmuştur. Taşra yöneticileri ise despot, yeteneksiz, bencil ve tembel olarak ifade edilmektedir. Yönetimde az da olsa mevcut olumlu gelişmeler ancak kişisel çabalarla gerçekleşmiştir. Şayet yöneticiler yetenekli ise kanunları uygulayarak halkın problemlerine çözüm bulmaya çalışmışır. Ancak yöneticiler beceriksiz ise halkın sorunları daha da artmıştır.

Gezginler seyahatnamelerinde Türk yöneticilerini ihmalkâr tavırları ve kendi çıkarları için çalıştıkları gerekçesiyle de eleştirmiştir. Keza bazı yöneticilerin halkın faydasına bir şeyler yapmaya çalıştığı, ancak görev yerlerinin sık değişmesinden dolayı çalışmaların yarıda kaldığı bildirilmektedir. Gezginlere göre Osmanlı ülkesinin içinde bulunduğu fakirlik ve ekonomik sorunlar, kaynakların verimli kullanılamamasından ve tembellikten kaynaklanmaktadır. Ancak yöneticilerin beceriksizliği ve yeteneksizliği, ahalinin tembel ve uyuşukluğu, kaynakların verimli 
kullanılamaması gibi söylemler, XIX. yüzyılda İngiliz gezi edebiyatında karşılaşılan klasik yaklaşımlardandır. Keza gezginlerin yönetim sistemiyle ilgili haksız eleştirilerinin Osmanlı teşkilat yapısını yeterince bilmemelerinden kaynaklandığı da söylenmelidir.

\section{Kaynakça}

Ahmed Lütfi Efendi. (1999). Vak'anüvis Ahmed Lütfi efendi tarihi. I, (A. Hezarfen, Trans.), İstanbul: Tarih Vakfi-Yapı Kredi Yayını.

Babacan, H. (2016). 19. yüzyıl ortalarında Kumanova'da ekonomik hayat ve meslekler. Z.Gölen ve A.Temizer (Ed), Osmanlı dönemi Balkan şehirleri 2 içinde (s. 603-619). Ankara: Gece Kitaplı̆ı.

Başkan, S. (1997). Tanzimat'tan Cumhuriyet'e Türkiye'de resim. Ankara Kültür ve Turizm Bakanlığı.

Benjamin, S. G. W. (1959). Türk ve Yunanlı, (Ş. Siber, Çev.), Ankara: Güzel Sanatlar Matbaası.

BOA, Y.EE., 108/29.

BOA, Y.PRK.EŞA., 38/24; 6/71.

BOA, Y.PRK.TŞF., 5/61.

BOA, Y.PRK.ZB., 25/91.

Bulut, Y. (2002). Oryantalizmin eleştirel kısa tarihi. İstanbul: Yöneliş Yayınları.

Burnaby, F. (2000). At sırtında Anadolu. (F. Taşkent, Çev.), İletişim Yayınları, 3. Bask1, İstanbul.

Busbecq, O. G. D. (ty). Türkiye’yi böyle gördüm. (A. Kurutluoğlu, Çev.), Tercüman 1001 Temel Eser.

Celkan, G. (1984). 18. ve 19. yüzyıl İngiliz seyahatnamelerinde Türkiye ve Türkler. (Yayımlanmamış doktora tezi). Ankara Üniversitesi, Ankara.

Cevdet Paşa. (1991a). Tezâkir (1-12). I (C. Baysun, Yay.Haz.), 3. Baskı, Ankara: Türk Tarih Kurumu Yayını.

Cevdet Paşa. (1991b). Tezâkir (13-20). II, (C. Baysun, Yay.Haz.), 3. Baskı, Ankara: Türk Tarih Kurumu Yayını.

Chishull, E. D. (1993). Türkiye gezisi ve İngiltere’ye dönüş 12 Eylül 1698-10 Şubat 1702. (B. Orhan, Çev.), İstanbul: Bağlam Yayını.

Çelik, Y. (2006). Tanzimat devrinde rüşvet-hediye ikilemi ve bu alandaki yolsuzlukları önleme çabaları. Türk Kültürü İncelemeleri Dergisi, (XV), 25-64.

Davis, E. J. (1879). Life in Asiatic Turkey. a journal of travel in Cilicia (Pedias and Trachoea), Isauria, and parts of Lycaonia and Cappadocia. London: Edward Stanford.

Davison, R. H. (1997). Osmanlı imparatorluğu'nda reform, 1856-1876. II, (O. Akınhay, Çev.), İstanbul: Papirüs Yayını.

Erhan, Ç. (1996). Rycaut'un kitabında Osmanlı toplum yapısına ilişkin veriler. Toplusal Tarih, VI (35), 49-57.

Ersoy, O. (1964). Bir İngiliz konsolosunun 1846 y1lında Erzurum'dan Kars'a seyahati. Tarih Araştırmaları Dergisi, III, (2-3). 237-249.

Fellows, C. (1852). Travels and researches in Asia Minor. London: John Murray Pub. 
Gölen, Z. (2016). Tanzimat dönemi Saraybosna'sında imar faaliyetlerinden örnekler. Z.Gölen ve A.Temizer (Ed), Osmanl dönemi Balkan şehirleri 2 içinde (s. 863-885). Ankara: Gece Kitaplı̆̆1.

Howard, G. W. F. (1978). Türk sularında seyahat. (Ş. S. Türet, Çev.) İstanbul: Tercüman 1001 Temel Eser nr. 117.

Kabbani, R. (1993). Avrupa'nın doğu imajı. (S. Tuncer, Çev.), İstanbul: Bağlam Yayınları.

Karaman, M. A., ve Tümtaş, M. S. (2016). Tarihsel olarak kent ve modernleşme sürecinde Selanik. Z.Gölen ve A.Temizer (Ed), Osmanlı dönemi Balkan şehirleri 1 içinde (s. 469-501). Ankara: Gece Kitaplı̆̆ı.

Keleş, E. (2005). Tanzimat dönemi’nde rüşvetin önlenmesi için yapılan düzenlemeler (18391858). Tarih Araştırmaları Dergisi, 24 (38), 259-280. Erişim adresi: https://dergipark.org.tr/tr/pub/tariharastirmalari/issue/47803/603841.

Kodaman, B. (2007). Osmanlı Devleti'nin yükseliş ve çöküş sebeplerine genel bakış. SDÜ Fen Edebiyat Fakültesi Sosyal Bilimler Dergisi, (16), 1-24.

Köprülü, M. F. (1986). Bizans müesseselerinin Osmanlı müsesseselerine tesiri. İstanbul: Ötüken Yayını.

Kurnaz Şahin, F. (2019). I. Dünya savaşı ve sonrasında kumarın yaygınlaşması ve Osmanlı Devleti'nin aldığı tedbirler. Selçuk Üniversitesi Edebiyat Fakültesi Dergisi, (41), 405-426.

Lewis, B. (1984). Doğu'ya giden bazı İngiliz seyyahları. (E. Erdim-S. Özbaran, Çev.), Tarih Incelemeleri Dergisi. II, 245-264.

Löschburg, W. (1998). Seyahatin kültür tarihi. (çev. Jasmin Traub), Ankara: Dost Kitabevi.

Madden, R. R. (1829). Travels in Turkey; Egypt; Nubia and Palestine in 1824, 1825, 1826, 1827. London: Henry Colburn.

Mayes, S. (2000). Sultan'ın orgu. (M. H. Spatar, Çev.), İstanbul: İletişim.

Moltke, H.V. (1969). Türkiye mektupları. (H. Örs, Çev.), İstanbul: Remzi Kitabevi.

Neave, D. L. (1978). Eski İstanbul'da hayat. (O. Öndeş, Çev.), İstanbul: Tercüman 1001 Temel Eser nr. 128.

Ortayl1, İ. (2006). Son imparatorluk Osmanl, Osmanlı'yl yeniden keşfetmek 2. İstanbul: 3. Bask1, Timaş Yayınları.

Önalp, E. (2000). Perulu bir gezginin gözüyle 1862 y1lında İstanbul. OTAM, (11), 875-884.

Öncel, S. (1969). XVIII. yüzyıl sonlarında Türkiye'de bir İtalyan gezgin: Giambattista Casti. Batı Dil ve Edebiyatları Araştırmaları Dergisi, I (4), 1969, s. 81-88.

Pardoe, M. J. (1997). 18. yüzyılda İstanbul. (B. Şanda, Çev.), İstanbul: İnkılap Kitabevi.

Pınar, İ. (1994). Gezginlerin gözüyle İzmir xix. yüzyıl I. İzmir: Akademi Kitabevi.

Poole, S.L. (1999). Lord Stratford Canning'in Türkiye hatıralart. (C. Yücel, Çev.), İstanbul: Tarih Vakfi Yurt Yayınları.

Raczynski, E. (1980). 1814'de İstanbul ve Çanakkale'ye seyâhat. (K. Turan, Çev.), İstanbul: Tercüman 1001 Temel Eser.

Robins, K. (1999). İmaj görmenin kültür ve politikası. (N. Türkoğlu, Çev.), İstanbul: Ayrıntı Yayınları. 
Sahhâflar Şeyhi-Zâde Seyyid Mehmed Es'ad Efendi. (2000). Vak'a-nüvîs Es 'ad efendi tarihi. (Bâhir efendi'nin zeyl ve ilâveleriyle), (1237-1241/1821-1826). (Z. Y1lmazer, Yay.Haz.), İstanbul: Osmanlı Araştırmaları Vakfı.

Slade, A. (1945). Sir Adolphus Slade'in (müşavir paşa) Türkiye seyahatnamesi ve Türk donanmasi ile yaptiği "Karadeniz” seferi. (A.R. Seyfioğlu, Çev.), Genelkurmay IX. Şube Yayınlar1.

Spohn, M. (1996). Her şey Türk işi, Almanların Türkler hakkında 500 yıllık (ön)yargıları, (L. Serdaroğlu, Çev.), İstanbul: Yapı Kredi.

Spry, W. J. J. (1895). Life of the Bosphorus doings in the city of the sultan Turkey past and present. London: H. S. Nichols Publishing.

Şahin, G . (2016). İngiliz gezgin Edwin John Davis'in seyahatnamesine göre XIX. yüzy1lın son çeyreğinde Adana ve çevresi. Osmanlı Medeniyeti Araştırmaları Dergisi, 2 (2), 60-77. DOI: 10.21021/osmed.217953.

Şahin, G. (2017). Ingiliz seyahatnamelerinde Osmanlı toplumu ve Türk imajı, İstanbul: Gökkubbe Yayınları.

Temizer, A. (2016). Osmanlı Devleti'nin Balkanlar'da kurduğu bir şehir: Akova. Z.Gölen ve A.Temizer (Ed), Osmanlı dönemi Balkan şehirleri 3, içinde (s. 1343-1368). Ankara: Gece Kitaplı̆̆ 1 Yayını.

Todorova, M. (2013). Balkanlar'ı tahayyül etmek. (D. Şendil, Çev.), 4. Bask1, İstanbul: İletişim Yayınları.

Tott, B.D., (ty). Türkler ve Tatarlara dâir hâtıralar. (M. R. Uzmen, Çev.), Tercüman 1001 Temel Eser, nr. 89.

Uzmen, E. (1969a). On dokuzuncu yüzyılın sonlarında Türkiyeye bir yabancı gözüyle bakış. Batı Dil ve Edebiyatları Araştırmaları Dergisi, 1 (4), 25-49.

Uzmen, E. (1969b). On dokuzuncu yüzyıl sonlarında bir İngiliz kadının gözüyle İstanbul. Batı Dil ve Edebiyatları Araştırmaları Dergisi, 1 (4), 49-80.

Uzun, M.İ. (1993). Caize. TDV İslâm Ansiklopedisi, 7, 28-29.

Uzunçarşı11, İ.H. (1949). On dokuzuncu asır başlarına kadar Türk-İngiliz münasebâtına dair vesikalar. Belleten, XIII (49-50-51-52), 573-648.

Uzunçarşı1l, İ.H. (1983) Osmanlı tarihi. III, 1 Kısım, Ankara: Türk Tarih Kurumu Yayını.

Ünlü, M. (2016). Priştine Kazasının Tanzimat sonrası gelişimi. Z.Gölen ve A.Temizer (Ed), Osmanlı dönemi Balkan şehirleri 1 içinde (s. 443-467). Ankara: Gece Kitaplığı.

Ünlü, S. (1982). Jacob Philipp Falmmerayer ve 19. asır Osmanlı Türkiye'si. Türk Dünyası Araştırmaları, 16 (Şubat), 142-154.

Ünlü, S. (1988). 18. yy. Alman edebiyatında Türkler. Türk Kültürü Araştırmaları, XXVI (1), 8390.

Vratislav, B. V. (1988). Baron Vratislav'ın anıları XVI. yüzyıl Osmanlı imparatorluğundan çizgiler. (M. S. Dilmen, Çev.), 3. Baskı, İstanbul: Milliyet Yayını.

Wittman, W. (1803). Travels in Turkey, Asia-Minor, Syria and across the desert into Egypt during the years 1799, 1800 and 1801 in company with Turkish army, and the British military mission. London: Richard Philips. 


\section{ETİK ve BİLIMSEL İLKELER SORUMLULUK BEYANI}

$\mathrm{Bu}$ çalışmanın tüm hazırlanma süreçlerinde etik kurallara ve bilimsel atıf gösterme ilkelerine riayet edildiğini yazar beyan eder. Aksi bir durumun tespiti halinde Afyon Kocatepe Üniversitesi Sosyal Bilimler Dergisi'nin hiçbir sorumluluğu olmayıp, tüm sorumluluk makale yazarlarına aittir. 